\title{
Dietary and lifestyle modification in metabolic syndrome: a review of randomized control trials in different population groups
}

Ishu Kataria ${ }^{1}$, Ravinder Chadha ${ }^{1}$, Renuka Pathak ${ }^{1}$

Department of Food and Nutrition, Lady Irwin College, University of Delhi, India

\section{Abstract}

The emergence of modernization coupled with sedentary lifestyle has resulted in the shift from the prevalence of diseases only due to under nutrition, to those caused by over nutrition. The augmentation of non-communicable diseases, thus, imposes double burden of disease, impeding the health of a nation. This upsurge has led to increase in prevalence and incidence of Metabolic syndrome which is a cluster of inter-related factors characterized by high fasting blood glucose, increased level of triglycerides, low levels of high density cholesterol, elevated blood pressure and abdominal obesity. The best way to combat this syndrome is to reduce the atherosclerotic risk, which can be carried out by modification in the diet and lifestyle - the first line of treatment of the syndrome. Thus, the present review was undertaken to understand the already existing as well as the current scenario specifically regarding the dietary and lifestyle interventions being carried out to overcome Metabolic syndrome. Of the randomized control trials reviewed, all except one reported improvement in Metabolic syndrome following intervention in diet and/or lifestyle modification either in certain components or overall syndrome within a period of 2 weeks- 1 year. These interventions to alter diet and lifestyle focus on weight reduction, promotion of regular physical activity, reduction of substance abuse, effectiveness of specific food items along with regulation of genes and various inflammatory markers. They have the potential to succeed only if they are executed early, and thus, offer enough evidence to develop appropriate public policies. However, the issue that is of utmost significance is of sustainability and compliance, which eventually decides the long-term success or failure of an intervention.

\section{Keywords}

Metabolic syndrome; Lifestyle; Intervention studies 


\section{Introduction}

With the advent of modernization, subsequent development of new facilities has led to sedentary lifestyle and consumption of high caloric diet, leading to an imbalance between the energy intake and energy expenditure $[1,2]$. This has led to rise in obesity which leads to other co-morbidities such as hypertension, insulin resistance, dyslipidemia, and diabetes eventually leading to Metabolic Syndrome (MetS) which acts as a precursor to cardiovascular disease (CVD) [1,2]. With continuing under nutrition, and escalation in over nutrition, there is double burden of diseases (communicable and noncommunicable) hovering on nations especially the developing countries which do not have adequate resources [3,4]. The global prevalence of chronic diseases is on rise in the developing countries with a share of $60 \%$ alone [5]. They will be accountable for three quarters of deaths worldwide by 2020 with a share of $71 \%$ due to CVD and $70 \%$ due to diabetes mellitus (DM) in the developing countries [6]. India will continue to hold its position as the highest DM patients' country in the world [7]. This increase in the prevalence of the non-communicable diseases (NCDs) currently as well as the high projected prevalence in the future is apprehensive. Strategizing public health policies and intervention programs is the top priority and need of the hour. Though pharmacological approach is one way of treating this problem, changes in the diet and lifestyle are the foremost hurdles that are needed to be crossed [8]. Therefore, the main objective of undertaking this review was to assess the effectiveness of dietary and lifestyle interventions in different population groups in overcoming MetS.

\section{Methodology}

In this article, we have reviewed the existing research regarding diet and lifestyle in treating or reducing MetS. We reviewed recent and past literature using Medline, PubMed (National Library of Medicine, Bethesda, MD, USA), Cochrane Library, Science Direct and Google Scholar databases. The keywords that were used included metabolic syndrome, diet, lifestyle, Mediterranean diet, intervention, insulin resistance, obesity, non- communicable diseases, hypertension, HDL, triglycerides, inflammation, genetics, CRP. Published randomized control trials (RCTs) on the effect of dietary and lifestyle interventions on MetS, which have been listed in the above mentioned databases from 2004 till 2012, have been included in this review.

\section{Metabolic syndrome}

\section{Terminology and diagnostic criteria}

The interrelationship between obesity, type $2 \mathrm{DM}$ and hypertension includes hyperinsulineamia as its essential feature [9], which led to Reaven's hypothesis that clustering of insulin resistance with glucose intolerance, hypertension, and dyslipidemia leads to a unique condition known as MetS or Syndrome X $[10,11]$. It is a cluster of interrelated factors characterized by high fasting blood glucose, increased level of triglycerides, low levels of high density lipoprotein (HDL), elevated blood pressure and abdominal obesity [12]. However the criteria for defining the syndrome are various (Table I).

Irrespective of the varying criteria proposed by different definitions, the prevalence of MetS is on the rise in both western as well as the Asian countries [1,13-15]. Increment in the proportion of diagnosed individuals can be related to increase in age as well as in body mass index (BMI) [16]. Not only the western societies, but also the developing countries are now getting engulfed in the burden of this problem. This 


\begin{tabular}{|c|c|c|c|c|c|c|c|}
\hline \multirow{2}{*}{$\begin{array}{l}\text { Dia- } \\
\text { gnostic } \\
\text { criteria }\end{array}$} & \multicolumn{7}{|c|}{ Expert group/Organization } \\
\hline & $\begin{array}{l}\text { WHO, } \\
1998\end{array}$ & $\begin{array}{l}\text { EGIR, } \\
1999\end{array}$ & $\begin{array}{l}\text { NCEP: ATPIII, } \\
2001\end{array}$ & $\begin{array}{l}\text { AACE, } \\
2003\end{array}$ & $\begin{array}{c}\text { AHA/NHLBI, } \\
2005\end{array}$ & $\begin{array}{l}\text { IDF, } \\
2005\end{array}$ & $\begin{array}{l}\text { Consensus } \\
\text { definition, } \\
2005^{*}\end{array}$ \\
\hline IFG & $>100 \mathrm{mg} / \mathrm{dl}$ & $\begin{array}{l}110 \mathrm{mg} / \mathrm{dl} \\
\text { or greater }\end{array}$ & $\begin{array}{l}110 \mathrm{mg} / \mathrm{dl} \\
\text { or greater }\end{array}$ & $\begin{array}{l}\text { Impaired } \\
\text { glucose } \\
\text { tolerance }\end{array}$ & $\begin{array}{l}100 \mathrm{mg} / \mathrm{dl} \\
\text { or greater }\end{array}$ & $\begin{array}{l}100 \mathrm{mg} / \mathrm{dl} \\
\text { or greater }\end{array}$ & $\begin{array}{l}100 \mathrm{mg} / \mathrm{dl} \\
\text { or greater }\end{array}$ \\
\hline WC & & $\begin{array}{l}M \geq 94 \mathrm{~cm} \\
W \geq 80 \mathrm{~cm}\end{array}$ & $\begin{array}{l}M>102 \mathrm{~cm} \\
W>88 \mathrm{~cm}\end{array}$ & & $\begin{array}{l}M \geq 102 \mathrm{~cm} \\
W \geq 88 \mathrm{~cm}\end{array}$ & \multirow{3}{*}{$\begin{array}{l}\mathrm{BMI}>30 \mathrm{~kg} / \mathrm{m}^{2} \\
\text { or elevated } \mathrm{WC} \\
\text { (according to } \\
\text { population and } \\
\text { country-specific } \\
\text { definitions)" }\end{array}$} & \multirow{3}{*}{$\begin{array}{l}\text { Elevated WC } \\
\text { (according to } \\
\text { population and } \\
\text { country-specific } \\
\text { definitions) }{ }^{\#}\end{array}$} \\
\hline WHR & $\begin{array}{l}M>0.9 \\
W>0.85\end{array}$ & & & & & & \\
\hline $\mathrm{BMI}$ & $>30 \mathrm{~kg} / \mathrm{m}^{2}$ & & & $\geq 30 \mathrm{~kg} / \mathrm{m}^{2}$ & & & \\
\hline TG & \multirow{2}{*}{$\begin{array}{l}\text { TG } \geq \\
150 \mathrm{mg} / \mathrm{dl} \\
\text { and/or } \\
\text { HDL-C: } \\
M<40 \mathrm{mg} / \mathrm{dl} \\
W<50 \mathrm{mg} / \mathrm{dl}\end{array}$} & \multirow{2}{*}{$\begin{array}{l}\geq 150 \mathrm{mg} / \mathrm{dl} \\
\text { and/or } \\
\mathrm{HDL}-\mathrm{C} \text { : } \\
<39 \mathrm{mg} / \mathrm{dl} \\
\text { in } M \text { or W }\end{array}$} & $\geq 150 \mathrm{mg} / \mathrm{dl}$ & \multirow{2}{*}{$\begin{array}{l}\text { TG } \geq \\
150 \mathrm{mg} / \mathrm{dl} \\
\text { and/or HDL-C: } \\
M<40 \mathrm{mg} / \mathrm{dl}, \\
W<50 \mathrm{mg} / \mathrm{dl}\end{array}$} & $\geq 150 \mathrm{mg} / \mathrm{dl}$ & $\geq 150 \mathrm{mg} / \mathrm{dl}$ & $\begin{array}{l}150 \mathrm{mg} / \mathrm{dl} \text { or } \\
\text { greater }\end{array}$ \\
\hline HDL- C & & & $\begin{array}{l}M<40 \mathrm{mg} / \mathrm{dl} \\
W<50 \mathrm{mg} / \mathrm{dl}\end{array}$ & & $\begin{array}{l}M<40 \mathrm{mg} / \mathrm{dl}, \\
W<50 \mathrm{mg} / \mathrm{dl}\end{array}$ & $\begin{array}{l}M<40 \mathrm{mg} / \mathrm{dl} \\
W<50 \mathrm{mg} / \mathrm{dl}\end{array}$ & $\begin{array}{l}M<40 \mathrm{mg} / \mathrm{dl} \\
W<50 \mathrm{mg} / \mathrm{dl}\end{array}$ \\
\hline $\mathrm{BP}$ & $\begin{array}{l}\geq 140 / 90 \\
\mathrm{mmHg}\end{array}$ & $\begin{array}{l}\geq 140 / 90 \\
\mathrm{mmHg}\end{array}$ & $\begin{array}{l}\geq 130 / 85 \\
\mathrm{mmHg}\end{array}$ & $\begin{array}{l}\geq 130 / 85 \\
\mathrm{mmHg}\end{array}$ & $\begin{array}{l}\geq 130 / 85 \\
\mathrm{mmHg}\end{array}$ & $\begin{array}{l}\geq 130 / 85 \\
\mathrm{mmHg}\end{array}$ & $\begin{array}{l}\geq 130 / 85 \\
\mathrm{mmHg}\end{array}$ \\
\hline $\begin{array}{l}\text { Any } \\
\text { other }\end{array}$ & - & - & - & - & - & - & $\begin{array}{l}\text { Microalbuminuria } \\
\geq 20 \mu \mathrm{g} / \mathrm{min} \text { or } \\
\geq 30 \mathrm{mg} / \mathrm{g}\end{array}$ \\
\hline
\end{tabular}

Table I. Diagnostic criteria for Metabolic Syndrome

$\mathrm{AACE}=$ American Association of Clinical Endocrinology; $\mathrm{AHA} / \mathrm{NHLBI}=$ American Heart Association/ National Heart, Lung, and Blood Institute; BMI = Body Mass Index; EGIR = European Group for the Study of Insulin Resistance; IDF = International Diabetes Federation; NCEP ATPIII = National Cholesterol Education Program Adult TreatMt Panel III; WC = waist circumference; WHR = Waist Hip ratio; $W H O=$ World Health Organization

$M=M ; W=W$

*Incorporating IDF and AHA/NHLBI definitions; IFG = impaired fasting glucose; TG = triglycerides; HDL$\mathrm{C}=$ High Density Lipoprotein Cholesterol; $\mathrm{BP}=$ blood pressure

\# Waist circumference: for Europeans, $>94 \mathrm{~cm}$ in $M$ and $>80 \mathrm{~cm}$ in W; and for South Asians, Chinese, and Japanese, $>90 \mathrm{~cm}$ in M and $>80 \mathrm{~cm}$ in W. For ethnic South and Central Americans, South Asian data are used, and for sub-Saharan Africans and Eastern Mediterranean and Middle East (Arab) populations, European data are used

rise can be attributed to the transition in the lifestyle from a traditional to a western one. The genesis of MetS and obesity in developing countries relates to demographic transition (shift to low fertility, low mortality, and higher life expectancy), and epidemiological transition (from widely prevalent infectious diseases to a pattern of a high prevalence of lifestyle related diseases) congregating genetics and environment [17-20]. Abdominal obesity [21-23], insulin resistance [10,11], along with physical inactivity [22,24], aging [25], hormonal imbalance [26], and atherogenic diet (a diet rich in saturated fat and cholesterol) are some factors that can exacerbate the risk for developing MetS, and consequently CVD [12].

\section{Prevalence and risk factors}

MetS is present worldwide, continuing to rise, with many countries now facing its burden [27]. According to the Framingham study, 25\% of new cases of CVD are accounted by MetS. Prevalence of MetS is on the rise in the developing countries (affecting nearly ${ }^{1 / 4^{\text {th }}}$ of the populations), including India. 
CVD accounted for $39 \%$ of deaths in India, attributing it to be the leading cause of mortality in 2005 [27]. Not only urban but rural populations are also being affected by it [28-30]. Prevalence of MetS is widespread, as can be observed through literature available over the years. There is not only an increasing trend in the South Asians residing in the Indian subcontinent but also in migrants [31], with an estimated prevalence of 20-25\% [32]. The contributory factors for MetS (Table II) are age [33-37], sex [36,38-40], region [36,38,41,42], income [43-46], Adult Treatment Panel III (ATPIII) or International

\begin{tabular}{|c|c|c|c|}
\hline Ref. & Design \& country & Sample & Finding(s) \\
\hline [34] & $\begin{array}{l}\text { Cross-sectional, } \\
\text { China }\end{array}$ & $\begin{array}{l}\mathrm{N}=2,334 \text { adults aged } 60 \text { to } \\
95 \text { years ( } 943 \text { men, } 1,391 \\
\text { women) }\end{array}$ & $\begin{array}{l}\text { - Prevalence ATPIII criteria: } 30.5 \% \text { ( } 17.6 \% \text { in men, } 39.2 \% \text { in } \\
\text { women) } \\
\text { - Prevalence IDF criteria: } 46.3 \% \text { ( } 34.8 \% \text { in men, } 54.1 \% \text { in women) } \\
\text { - Odds ratio for CVD, stroke and PAD are higher among those } \\
\text { with MetS (irrespective of criterion) }\end{array}$ \\
\hline [35] & $\begin{array}{l}\text { Cross-sectional, } \\
\text { Australia }\end{array}$ & $\begin{array}{l}\mathrm{N}=5,850 \text { of which } \\
4,060 \text { had biochemical } \\
\text { examination }\end{array}$ & $\begin{array}{l}\text { - Prevalence IDF criteria: } 22.8 \text { (26.4\% in men, } 15.7 \% \text { in women }) \\
\text { - Prevalence ATPIII criteria: } 15.0 \%(19.4 \% \text { in men, } 14.4 \% \text { in } \\
\text { women) }\end{array}$ \\
\hline [36] & $\begin{array}{l}\text { Cross-sectional } \\
\text { Jaipur, India } \\
\text { (Urban) }\end{array}$ & $\begin{array}{l}\mathrm{N}=1,091 \text { ( } 532 \text { men; } 559 \\
\text { women) adults }>20 \text { years }\end{array}$ & $\begin{array}{l}\text { - Prevalence ATPIII criteria: } 345(31.6 \%) \text { subjects - males } 122 \\
(22.9 \%) \text {; females } 223(39.9 \%)(p<0.001) \\
\text { - Increase in prevalence with age }(p<0.05)\end{array}$ \\
\hline [37] & $\begin{array}{l}\text { Prospective, } \\
\text { Case-Control } \\
\text { U.S.A }\end{array}$ & $\begin{array}{l}\mathrm{N}=\text { cases } 32,826 \text { women } \\
\mathrm{N}=785 \text { controls }\end{array}$ & $\begin{array}{l}\text { - Baseline levels of } T N F, I L \text {, and CRP were significantly higher in } \\
\text { cases than controls }(P \leq 0.001) \\
\text { - Significant association of CRP with risk of DM } \\
\text { (OR: } C R P=3.99, P<0.001)\end{array}$ \\
\hline [38] & $\begin{array}{l}\text { Cross-sectional } \\
\text { Chandigarh, India } \\
\text { (Urban) }\end{array}$ & $\begin{array}{l}\text { Adults aged } 18 \text { years and } \\
\text { above }\end{array}$ & $\begin{array}{l}\text { - Prevalence IDF criteria: } 287 \text { adults }(47.4 \%) \text { - females } 171 \\
(59.6 \%) \text {; males } 116(40.4 \%) \\
\text { - Prevalence ATPIII criteria: } 233 \text { adults }(38.5 \%) \text { - females } 141 \\
(44.8 \%) \text {; males } 116(39.5 \%)\end{array}$ \\
\hline [41] & $\begin{array}{l}\text { Cross-sectional } \\
\text { Toto tribe, Bhutia } \\
\text { tribe }\end{array}$ & $\mathrm{N}=258$ (Toto); 310 (Bhutia) & $\begin{array}{l}\text { - Prevalence ATPIII criteria: } 30-50 \% \text { in Bhutia tribe; } 4-9 \% \text { in Toto } \\
\text { tribe } \\
\text { - MetS not necessarily related to modernization }\end{array}$ \\
\hline [43] & $\begin{array}{l}\text { Cross-sectional } \\
\text { London, U.K } \\
\text { (High, Middle, } \\
\text { Lower income) }\end{array}$ & $\begin{array}{l}\mathrm{N}=1,509 \text { women; } 4,090 \\
\text { men (aged } 45.2-68.9 \text { years) }\end{array}$ & $\begin{array}{l}\text { - Inverse association of own and household income and wealth } \\
\text { with MetS (P<0.001). } \\
\text { - Increased prevalence (WHO criteria) in men than women } \\
\text { (wealthiest: } 12.0 \text { and } 5.7 \% \text {; poorest: } 23.6 \text { and } 20.1 \% \text { ) }\end{array}$ \\
\hline [44] & $\begin{array}{l}\text { Cross-sectional } \\
\text { France, Europe }\end{array}$ & $\begin{array}{l}\mathrm{N}=1,695 \text { men; } \\
1,664 \text { women, } \\
\text { (aged } 35-64 \text { years) }\end{array}$ & $\begin{array}{l}\text { Prevalence ATPIII criteria: } 390 \text { ( } 23.0 \%) \text { men; } 381(16.9 \%) \\
\text { women } \\
\text { - Inverse association of household income with MetS }(\mathrm{P}<0.004) \\
\text { in women (Sex-specific increase) }\end{array}$ \\
\hline [46] & $\begin{array}{l}\text { Cross-sectional } \\
\text { London, U.K } \\
\text { (Income-wise } \\
\text { stratification) }\end{array}$ & $\begin{array}{l}\mathrm{N}=4978 \text { men; } 2035 \text { women } \\
\text { (aged } 39-63 \text { years) }\end{array}$ & $\begin{array}{l}\text { Inverse association between obesity, fibrinogen and MetS, and } \\
\text { socioeconomic status }\end{array}$ \\
\hline [48] & $\begin{array}{l}\text { Cross-sectional } \\
\text { Zulia, Venezuela }\end{array}$ & $\begin{array}{l}\mathrm{N}=3108 \text { men and women } \\
\text { (aged } \geq 20 \text { years) }\end{array}$ & $\begin{array}{l}\text { - Prevalence ATPIII criteria: men } 31.2 \% \text {, women } 24.1 \% \\
\text { - Family history of diabetes, obesity, HT and sedentary lifestyle } \\
\text { were positively associated with the MS }\end{array}$ \\
\hline [49] & $\begin{array}{l}\text { Cross-sectional } \\
\text { Muscat, Oman }\end{array}$ & $\begin{array}{l}\mathrm{N}=1419 \text { adults } \\
\text { (aged } \geq 20 \text { years) }\end{array}$ & $\begin{array}{l}\text { - Age adjusted prevalence ATPIII criteria: } 21.0 \% \text {; men } 19.5 \% \text {, } \\
\text { women } 23.0 \%(p=0.236)\end{array}$ \\
\hline$[50]$ & $\begin{array}{l}\text { Cross-sectional } \\
\text { Pan-India } \\
\text { (Industrial } \\
\text { population) }\end{array}$ & $\begin{array}{l}\mathrm{N}=19,973 \text { for } \\
\text { questionnaire survey; } \\
10,442 \text { biochemical testing } \\
\text { (aged } 20-69 \text { years) }\end{array}$ & $\begin{array}{l}\text { - Prevalence ATPIII criteria: } 26.6 \% \text { (men } 20.9 \% \text {; women } 36.3 \% \text { ) } \\
\text { - Prevalence IDF criteria: } 35.4 \% \text { (men } 29.4 \% \text {; women } 46.1 \% \text { ) }\end{array}$ \\
\hline
\end{tabular}

Table II. Prevalence of Metabolic Syndrome 


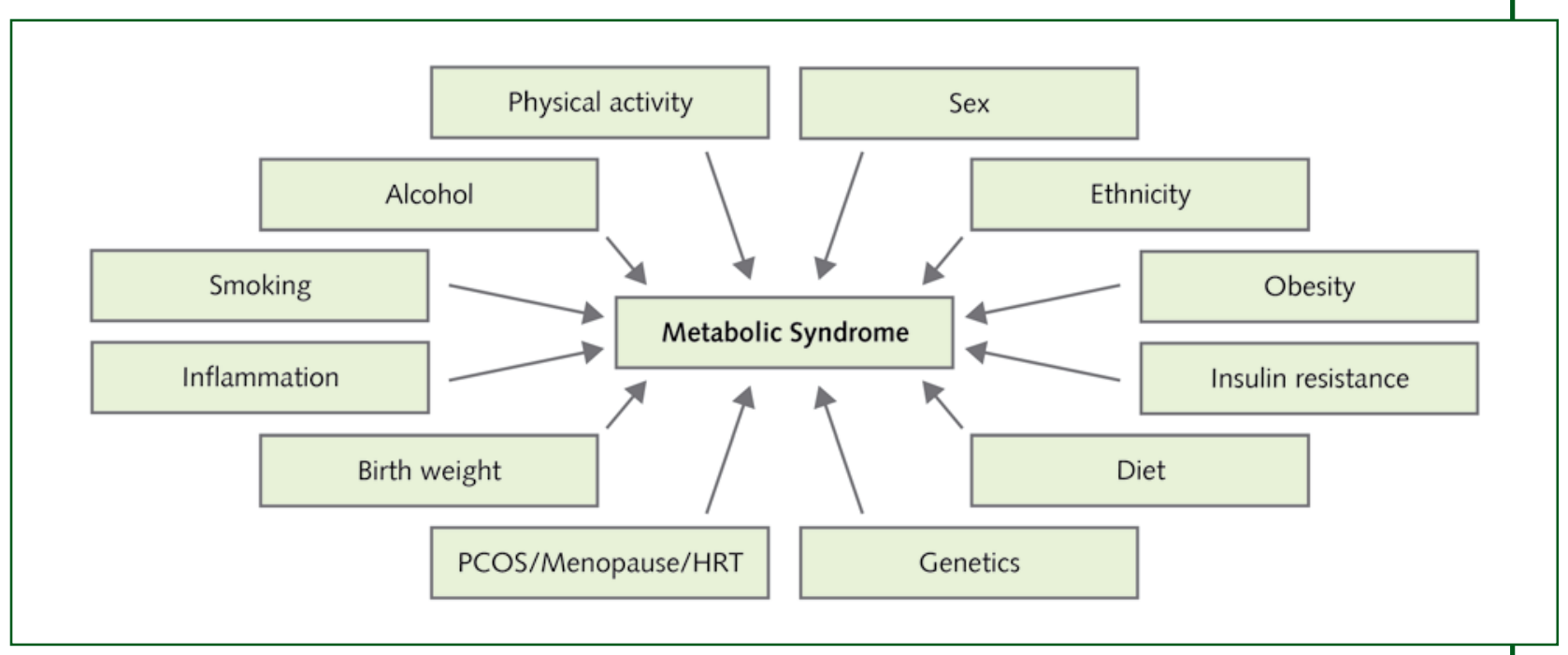

Figure 1. Risk factors for Metabolic Syndrome $[10,12,21,22,25,26,56,57]$

HRT $=$ Hormone Replacement Therapy; PCOS = Poly Cystic Ovary Syndrome

Diabetes Federation (IDF) criteria [17,47-49] and occupation [50,51]. In light of the evidence provided in Table II, it is clear that there exists an inverse relationship between income and MetS in developed countries $[43,44,46]$; however, the situation is reversed in the developing countries where the prevalence increases with the rise in socioeconomic status [38]. This can be attributed to the fact that in developing countries, as the income increases, more amount of the income is spent on fats and sugars; while in the developed countries, those with the lower income prefer to buy foods rich in fats and sugar as they are much cheaper than other food items. Though MetS portrays low prevalence among youth, clustering of risk factors can result in the progression towards the syndrome in adulthood, thus, advocating early identification for alleviation of the problems related to the syndrome [52,53] is essential. MetS is a challenging condition as it is not a discrete entity but consists of multitude of risk factors (Figure 1). The risk varies in an individual depending on the aggregation of metabolic and non-metabolic risk factors [54]. According to the American Heart Association (AHA) statement [55], atherogenic dyslipidemia, elevated blood pressure, and elevated plasma glucose are the most familiar risk factors. Other factors include abdominal obesity [21-23], insulin resistance [10,11], along with physical inactivity [22,24], aging [25], hormonal imbalance [26], and atherogenic diet [12]. Relationship of MetS with sex, age, degree of obesity and socio-economic status has also been confirmed [56,57]. Ethnicity [25,58,59], smoking [60,61,62], alcohol consumption [63-66], inflammation [67,68,37], genetic predisposition [69,70], low birth weight $[71,72]$, polycystic ovary syndrome (PCOS), menopause, and hormone replacement therapy (HRT) [73] have also shown their association with the syndrome. A solitary factor cannot purport to augmentation of the syndrome; therefore, interaction amongst various domains relating to it, holds colossal worth that needs to be evaluated with the help of longitudinal studies [27].

\section{Treatment of Metabolic Syndrome}

\section{Pharmacological treatment}

According to AHA [55], the targeted treatment for the syndrome underlines the fact that the foremost goal is to reduce the atherosclerotic risk. This involves directing attention at the major risk factors so 
that the treatment is offered to the patients' relative to their risk. The first line of intervention is however, the lifestyle therapies whether the risk is long or short term. To achieve maximum benefit, weight reduction through diet modification and increased physical activity results in risk reduction concurrently. Drug/pharmacological therapy isn't syndrome specific but risk factor specified [55]. Drugs such as antihypertensive for controlling blood pressure, aspirin for those with a greater risk (more than $10 \%$ or 10 year risk) of developing the disease, and statins, fibrates and niacin for dyslipidemias are suggested in extreme cases where diet and lifestyle modification is not enough alone. However, maintenance of blood glucose levels with haemoglobin $\mathrm{A}_{\mathrm{C}}$ level of less than $7.0 \%$ has been the key recommendation [55]. Nonetheless, the foundation of treatment for MetS is diet and lifestyle modification.

\section{Dietary modification}

Modernization in the field of agriculture has led to changes in the diet which alongside a sedentary lifestyle has contributed to increased consumption of diets rich in fat and cholesterol leading to an overall positive energy balance [74]. Therefore, poor diet is an important component of the syndrome that needs to be targeted for its reduction and treatment. The efficacy of Mediterranean diet (MeD) on MetS has been observed through many studies [75-79]. The Mediterranean Dietary pattern typically emphasizes fruits, cooked vegetables and legumes, grains (whole, not refined) and, in moderation, wine, nuts, fish and dairy products, particularly yogurt and cheese. It is a food pattern that has the potential of improving health and quality of life in people who adhere to it appropriately characterizing a way of life and culture [80]. Specifically, each component of Mediterranean dietary pattern has its own significance that holds a key in obviating MetS. Various dietary interventions have confirmed its role in MetS management (Table III), where they have shown significant weight loss, improvement in the MetS components [75,81], improvement in body composition and cardio-metabolic fitness [82], increase in long chain N3 poly unsaturated fatty acids [79] and decrease in high sensitive C-reactive protein (hsCRP) and insulin resistance [83].

A cross-sectional study with the participants ( $\mathrm{n}=808$ adults with high CVD risk) of the PREDIMED trial was conducted to understand the relationship between $\mathrm{MeD}$ and MetS. Negative association of the syndrome with high MeD score ( $\geq 9$ points) was observed $(\mathrm{p}<0.001 ; \mathrm{OR}=0.44)$ with specific components conferring conclusive benefits like olive oil, legumes and red wine [84]. Following this, the PREDIMED study investigators compared the effect of 2 interventions using MeD with a low fat diet on MetS with 1 year clinical trial [85]. MeD diet +1 1/wk of virgin olive oil, MeD diet $+30 \mathrm{~g} /$ day of mixed nuts and advice on low fat diet (control) was given, wherein MetS was defined using ATPIII criteria. After adjustment for age, sex, weight changes and baseline obesity status, the odds ratio $(\mathrm{OR})$ for MetS decline was more for the nuts group $(\mathrm{OR}=1.7)$ than for the virgin olive oil group $(\mathrm{OR}=1.3)$, substantiating the importance of $\mathrm{MeD}$ diet as a useful tool in MetS management. Similarly, women diagnosed with MetS in Korea ( $\mathrm{n}=52$; mean age, $62.7 \pm 9.0$ years) were subjected to a therapeutic lifestyle management program for 6 months. It included health monitoring, counselling, health education, exercise, and dieting as its components alongside measuring health related Quality of Life (QOL) index and metabolic risk factors at baseline, 3, 6 and 12 months. The program exhibited significant reductions in body weight $(\mathrm{p}<0.001)$, waist circumference $(\mathrm{WC})(\mathrm{p}<0.001)$, general $(\mathrm{p}<0.001)$ and mental health $(\mathrm{p}=0.027)$, and vitality $(\mathrm{p}=0.008)$; with decrement in body weight and WC even sustaining after intervention. Another ongoing trial in Spain is being carried out to lessen the incidence of MetS, which is apparently on the rise [86]. The reduction of the metabolic syndrome in Navarra-Spain (RESMENA-S) study is a randomized prospective parallel design ( $\mathrm{n}=50)$ encompassing personalized weight loss (30\% energy restriction) diet, with a macronutrient distribution (carbohydrate/fat/protein) of 40/30/30, high meal frequency (7/day), low glycemic index/load and high antioxidant capacity as well as a high adherence to the $\mathrm{MeD}$ aimed to lower the incidence of the syndrome [86]. 


\begin{tabular}{|c|c|c|c|c|}
\hline Ref. & Country & Sample & Intervention & Finding(s) \\
\hline [75] & Spain & $\begin{array}{l}\mathrm{N}=45 \\
\text { sedentary } \\
\text { adults } \\
(50-66 \text { years })\end{array}$ & $\begin{array}{l}\text { Two groups: (a) hypocaloric, } \\
\text { normoproteic MeD; and }(b) \\
\text { the same diet plus periodized } \\
\text { moderate-to-high intensity training } \\
\text { (MeDE) for } 12 \text { weeks }\end{array}$ & $\begin{array}{l}\text { Significant weight loss and improvement } \\
\text { in MetS components was achieved with } \\
\text { hypocaloric, normoproteic Mediterranean diet } \\
(p<0.05) \\
\text { - More significant weight loss was achieved } \\
\text { with the combination of MeD and moderate } \\
\text { intensity physical activity post } 12 \text { weeks } \\
\text { compared to MeD alone }(p<0.05)\end{array}$ \\
\hline [76] & U.S.A & $\begin{array}{l}\text { Women; } \\
\mathrm{n}=44 \text { control; } \\
\mathrm{n}=45 \\
\text { intervention }\end{array}$ & $\begin{array}{l}\text { Control (Mediterranean-style low- } \\
\text { glycemic-load diet) vs. intervention } \\
\text { (diet + Medical food containing } \\
\text { phytosterols, soy proteins }\end{array}$ & $\begin{array}{l}\text { Decreases in fat and sugar intake }(p<0.001) \text {, } \\
\text { and increase in DHA and EPA }(p<0.001) \text { were } \\
\text { observed in both groups } \\
\text { - Significant reduction in all components of MetS } \\
(p<0.05) \text { and plasma homocysteine levels was } \\
\text { seen in the diet + medical food group }(p<0.01) \\
\text { as compared to diet only group }\end{array}$ \\
\hline [79] & Germany & $\mathrm{N}=101$ adults & $\begin{array}{l}\text { Med diet group }+100 \text { hrs of } \\
\text { education }(n=48) \text { vs. written advice } \\
\text { only group }(n=53)\end{array}$ & $\begin{array}{l}\text { - Increase in the consumption of fish, fruits/ } \\
\text { vegetables and moderately of canola/olive oil } \\
\text { and increased plasma concentrations of long- } \\
\text { chain n-3 polyunsaturated fatty acids in the } \\
\text { intervention group } \\
\text { - No change in the markers of inflammation like } \\
\text { hs-CRP, fibrinogen, fasting insulin, homocysteine, } \\
\text { serum lipids and plasma fatty acids }\end{array}$ \\
\hline [81] & $\begin{array}{l}\text { Houston, } \\
\text { Texas, } \\
\text { USA }\end{array}$ & $\begin{array}{l}\mathrm{N}=81 \\
\mathrm{men})\end{array}$ & $\begin{array}{l}12 \text { week, } 3 \text { groups: } 0,8 \text {, or } 16 \text { fluid } \\
\text { ounces of low sodium vegetable } \\
\text { juice }\end{array}$ & $\begin{array}{l}\text { More weight loss, high consumption of Vitamin } \\
\text { C, potassium, and dietary vegetables was } \\
\text { observed in the juice drinking group }(p<0.05) \\
\text { compared to those only on diet counselling }\end{array}$ \\
\hline [82] & $\begin{array}{l}\text { Whyalla, } \\
\text { South } \\
\text { Australia }\end{array}$ & $\begin{array}{l}\mathrm{N}=153 \text { obese } \\
\text { adults with } \\
\text { MetS }\end{array}$ & $\begin{array}{l}\text { Randomized to intervention or } \\
\text { control for } 16 \text { weeks. INT group: } \\
\text { lifestyle program which provided a } \\
\text { curriculum and practical strategies } \\
\text { on 1) dietary and Physical Activity } \\
\text { information based on national } \\
\text { guidelines, 2) behavioural self- } \\
\text { management tools, 3) food-label } \\
\text { reading, supermarkets tour and } \\
\text { cooking, 4) exercise sessions, and } \\
\text { 5) peer-group support }\end{array}$ & $\begin{array}{l}\text { - Significant improvement observed in body } \\
\text { composition }(p<0.01), \text { physical and cardio- } \\
\text { metabolic fitness }(p<0.01) \text { with minimally } \\
\text { prescriptive lifestyle intervention program }\end{array}$ \\
\hline [83] & $\begin{array}{l}\text { Naples, } \\
\text { Italy }\end{array}$ & $\begin{array}{l}\mathrm{N}=180 \\
\text { adults ( } 99 \\
\text { men and } 81 \\
\text { women) with } \\
\text { MetS (ATPIII } \\
\text { criteria): } 90 \\
\text { in control } \\
\text { and } 90 \text { in } \\
\text { intervention } \\
\text { group }\end{array}$ & $\begin{array}{l}\text { Patients in the intervention } \\
\text { group were instructed to follow } \\
\text { a Mediterranean-style diet and } \\
\text { received detailed advice about how } \\
\text { to increase daily consumption of } \\
\text { whole grains, fruits, vegetables, } \\
\text { nuts, and olive oil; patients in the } \\
\text { control group followed a prudent } \\
\text { diet (carbohydrates, } 50-60 \% \text {; } \\
\text { proteins, } 15-20 \% \text {; total fat, <30\%) }\end{array}$ & $\begin{array}{l}\text { Post } 2 \text { years significant increase in fruit, } \\
\text { vegetables, whole grains, olive oil and nuts } \\
\text { consumption }(p<0.001) \text {, and decrease in mean } \\
\text { body weight was observed in the intervention } \\
\text { group ( } p<0.001) \\
\text { Significant improvement in the endothelial } \\
\text { function score }(p<0.001) \text { and reduction in the } \\
\text { hs-CRP values }(p=0.01) \text { and insulin resistance } \\
(p<0.001) \text { was also observed in the intervention } \\
\text { group }\end{array}$ \\
\hline [134] & U.S.A & $\begin{array}{l}\mathrm{N}=54 \\
\text { normal } \\
\text { weight young } \\
\text { women; } 18 \\
\text { to } 31 \text { years }\end{array}$ & $\begin{array}{l}\text { Two year exercise intervention. } \\
\text { Three sessions of resistance exercise } \\
\text { plus } 60 \text { minutes of jumping rope } \\
\text { per week or a control group for } 24 \\
\text { months + dietary assessment for Ca } \\
\text { intake using a } 3 \text { day diet record }\end{array}$ & $\begin{array}{l}\text { - High Ca intake led to lower weight gain and } \\
\text { body fat after } 2 \text { years of intervention, regardless } \\
\text { of the exercise group allocation }\end{array}$ \\
\hline
\end{tabular}

Table III. Effectiveness of RCTs to control Metabolic Syndrome

$\mathrm{Ca}=$ Calcium; DHA = Decosa Hexanoic Acid; EPA = Eicosa Pentanoic Acid; hs- $\mathrm{CRP}=$ High sensitive $\mathrm{C}$ Reactive

Protein; $\mathrm{MeD}=$ Mediterranean Diet; $\mathrm{MeDE}=$ Mediterranean Diet + Exercise; MetS $=$ Metabolic Syndrome 
Considering effectiveness of specific food items in MetS reduction, consumption of boiled artichoke meal had no beneficial effect in patients $(n=19)$ with MetS in a RCT which was undertaken to ascertain if artichoke could be beneficial in lowering the post - prandial glucose levels and insulin levels in MetS patients [87]. However, Lerman et al. [88] demonstrated benefits from a Mediterranean-style, low-glycemic-load diet $(\mathrm{n}=12)$ and phytochemical-enhanced diet $(\mathrm{n}=12)$ consumed over 12 weeks period coupled with identical aerobic exercise counselling. The phytochemical-enhanced diet comprised of low-glycemic-load diet plus a medical food containing soy protein and plant sterols and a nutraceutical containing hops rho iso-alpha acids and acacia proanthocyanidins. Improvement in the levels of total cholesterol, low-density lipoprotein cholesterol (LDL-C), non-high-density lipoprotein cholesterol (non-HDL-C), cholesterol/HDL-C, triglyceride/HDL-C, apolipoprotein B (apo B), apo B/apo A-1, homocysteine, total LDL particle number, and large HDL particle number were observed in the phytochemical enhanced diet group compared to only Med diet group ( $\mathrm{p}<0.05)$. Nuts, as a MeD component, have shown additional benefits regarding improvement of the syndrome, if incorporated along with lifestyle counselling. In a RCT [89] among 283 MetS screened patients, $30 \mathrm{~g} / \mathrm{d}$ flaxseed or $30 \mathrm{~g} / \mathrm{d}$ walnuts were given with lifestyle counselling, while the third group received only counselling. Post 12 weeks, prevalence of the syndrome decreased significantly in all 3 groups. However, the severity was most significantly reduced in the walnuts group compared to only lifestyle counselling group ( $\mathrm{p}=0.045)$. Similar reduction in MetS has also been observed with food containing phytosterols and soy proteins [76]. Therefore, specific foods such as nuts or phytochemicals might have a potential in prevention and management of the syndrome, however, more work is clearly warranted in this area to bring out their effectiveness.

\section{Which is the best dietary composition to combat MetS?}

Though diet and lifestyle modification seem to be the first line of treatment for the syndrome, the uncertainty with the exact diet composition for reduction of the syndrome still remains elusive [90]. Two diets viz. diet relatively rich in carbohydrate (65\% of energy as carbohydrate, $13 \%$ as protein, and $22 \%$ as fat: $17 \%$ as unsaturated fat) or a diet that was low in carbohydrate and high in protein and in monounsaturated fat ( $48 \%$ of energy as carbohydrate, $19 \%$ as protein, and $33 \%$ as fat: $24 \%$ as unsaturated fat), differing in their composition were tested on 100 obese patients with MetS. At the end of 5 months, though the syndrome components decreased in both diet groups, a greater significant decrease in hypertension $(\mathrm{p}<0.05)$ prevalence and hypertriacylglycerolemia $(\mathrm{p}<.001)$ were seen with the low carbohydrate ( $\mathrm{CHO}$ ) diet group [90]. Alleviation of the factors determining the syndrome was ascertained via a low calorie diet with or without exercise, in 323 overweight Japanese women (24-67 years; BMI: $25-40 \mathrm{~kg} / \mathrm{m}^{2}$ ) in a 3 months program. CART (Classification and regression tree) analysis revealed that a weight reduction of $8.1 \%$ in baseline body weight resulted in improvement of at least 1 MetS component was observed among women $\leq 41.5$ years; $\geq 13.0 \%$ weight loss led to improvement in abdominal obesity; improvement in blood pressure; $\geq 13.2 \%$ weight loss led to improvement in hyperglycemia. Thus, a modest weight loss of $8-13 \%$ was nearly effective in ameliorating individual components of MetS in overweight Japanese women [91].

Dietary modification to counter the syndrome is also an important strategy to reduce cardiovascular risk. Four diets were randomly assigned to 337 patients: two high fat diets, one rich in saturated fat (HSFA) and the other rich in monounsaturated fat (HMUFA), and two low fat diets, one high in complex carbohydrates (LFHCC) supplemented with $1.24 \mathrm{~g} /$ day of long-chain n-3 polyunsaturated fatty acids (LFHCC n-3) and the other LFHCC diet with placebo (LFHCC). Decrement in the prevalence of MetS $(p<0.028)$, lowering of waist circumference, blood pressure and hypertriglyceridemia $(p<0.05)$ was observed with the LFHCC n-3 diet in contrast to HSFA, HMUFA and LFHCC groups [92]. Meal replacement can also be an effective technique in reduction of MetS risk factors even over a short period of time. Ninety overweight or obese subjects ( 45 years; BMI $31.5 \pm 2.3 \mathrm{~kg} / \mathrm{m}^{2}$ ) were either randomized to a fat restricted low calorie diet group $(\mathrm{LCD}-\mathrm{G})(\mathrm{n}=30)$ which received 2 dietary counselling 
sessions and instructions on physical activity or in the meal replacement diet group (MRD-G) (n=60) that received the same lifestyle education and replaced 2 of their meals with low calories high protein soy drink. Subjects in the MRD-G lost significantly more weight $(\mathrm{p}<0.01)$, had higher reduction in WC $(p<0.01)$, triglycerides $(p<0.01)$, syndrome prevalence $(p<0.05)$, leptin and insulin levels $(p<0.01)$ in comparison to LCD-G [93]. Often, it becomes difficult to attribute exactly whether weight loss or behaviour change or both are responsible for successful reduction of the syndrome [94]. This pertinent aspect led to investigation in men and post menopausal women with elevated LDL and lowered HDL, to ascertain the effects of low fat diet and exercise - alone and in combination, on MetS. Maximum change in MetS was observed with low fat diet in men $(p=0.04)$ and women $(p=0.045)$ in comparison to controls. Yet, after adjustment for body fat change, there wasn't any effect of low fat diet and exercise on the syndrome. As a result, it was the body fat that had a significant association with MetS in both men $(p<0.0001)$ and women $(p=0.004)$, and emerges as the crucial component to be targeted [94]. Hence, through the evidence cited, it appears that low calorie diets have the potency to cause a resultant decrease in various components of MetS.

\section{Lifestyle modification}

The term 'Lifestyle' implies the way of living. It encompasses the existence of individuals, families and societies with their corresponding behaviour in different settings such as physical, social, psychological and economic [95]. With industrialization, emergence of lifestyle diseases is on the rise, owing to longer life span and faulty lifestyle. The resultant non-communicable and chronic diseases impose burden on the health services of a country especially the developing nations, leading to longer years of disability and death, eventually leading to poor productivity, and thus, hampering the growth of a nation [95]. Hence, interventions to promote healthy lifestyle to curb the development of MetS are the need of the hour (Table IV). Regular physical activity along with proper diet i.e. rich in fibre, low calorie or energy restricted, has shown beneficial effects in reduction of MetS [96], increase in the intake of fruits and vegetables [96,97], decrease in BMI, WC, triglycerides, LDL, insulin resistance [98-100] and inflammatory markers such as interleukin-1 (IL-1), interleukin-6 (IL-6) and tumor necrosis factor- $\alpha$ (TNF- $\alpha$ ) [99].

Most lifestyle intervention programs are based on weight reduction that has proved successful, demonstrating significant improvements in all components of the syndrome [101-103].

\begin{tabular}{|c|c|c|c|c|}
\hline Ref. & Duration & Sample & Intervention & Finding(s) \\
\hline [96] & 10 weeks & $\begin{array}{l}\mathrm{N}=50 \text { overweight } \\
\text { adults ( } \mathrm{n}=22 \\
\text { general } \\
\text { educational } \\
\text { group; } \mathrm{n}=28 \text { high } \\
\text { fibre nutrition } \\
\text { group) }\end{array}$ & $\begin{array}{l}\text { Lifestyle intervention focusing } \\
\text { on physical activity and } \\
\text { high fibre intake via dietary } \\
\text { counselling and supervised } \\
\text { exercise }\end{array}$ & $\begin{array}{l}\text { - Higher intake of fruits and vegetables, higher } \\
\text { plasma } \beta \text {-carotene levels, greater reductions } \\
\text { in body fat, waist circumference, obesity } \\
\text { class III, obesity class II and } 24 \% \text { reduction of } \\
\text { MetS was seen in the group } 2 \text { as compared } \\
\text { to group } 1\end{array}$ \\
\hline \multirow[t]{3}{*}{ [97] } & $\begin{array}{l}6 \text { month } \\
\text { intervention }\end{array}$ & $\begin{array}{l}\mathrm{N}=816 \text { male blue } \\
\text { and white collar } \\
\text { workers }\end{array}$ & $\begin{array}{l}\text { Intervention consisted of } \\
\text { individual counselling using } \\
\text { motivational interviewing } \\
\text { techniques, and was delivered } \\
\text { by an occupational physician or } \\
\text { occupational nurse }\end{array}$ & $\begin{array}{l}\text { - Statistically significant improvement in the } \\
\text { snack }(b-1.9,95 \% \mathrm{Cl}=-3.7 ;-0.02) \text { and fruit } \\
\text { intake }(\mathrm{b} 1.7,95 \% \mathrm{Cl}=0.6 ; 2.9) \text { at } 6 \text { months } \\
\text { - Sustained snack and fruit intake improvement } \\
\text { at } 12 \text { months } \\
\text { - Beneficial impact on smoking (OR: } 0.3) \text { at } 6 \\
\text { months } \\
\text { - No significant impact on leisure time } \\
\text { physical activity }\end{array}$ \\
\hline & & & & continues > \\
\hline & & $d$ & & Reviews in Health Care $2013 ; 4(4)$ \\
\hline
\end{tabular}


$>$ follows

\begin{tabular}{|c|c|c|c|c|}
\hline Ref. & Duration & Sample & Intervention & Finding(s) \\
\hline [98] & 6 months & $\begin{array}{l}\mathrm{N}=60 \text { (mean } \\
\text { age } 40.0 \pm 8.5 \\
\text { years) non- } \\
\text { alcoholic fatty } \\
\text { liver disease } \\
\text { (NAFLD) patients }\end{array}$ & $\begin{array}{l}\text { Regular aerobic exercise for } 30 \\
\text { min/d, for at least } 5 \mathrm{~d} / \text { week }+ \\
\text { Moderate Energy restricted diet } \\
\text { containing } 60 \% \text { carbohydrate, } \\
20 \% \text { fat, } 20 \% \text { protein and } \\
200 \mathrm{mg} \text { cholesterol (NCEP Step } \\
\text { I diet, ( } 25 \mathrm{kcal} / \mathrm{kg} \text { ideal body } \\
\text { weight) was advised to patients } \\
\text { with high BMI }\end{array}$ & $\begin{array}{l}\text { Significant decrement in BMI, WC and } \\
\text { Alanine amino Transferase (ALT) was } \\
\text { observed post } 6 \text { months }(p<0.01) \text { in } 45 \\
\text { exercise compliant patients } \\
\text { - No significant changes in BMI, WC and ALT } \\
\text { were seen in } 15 \text { non-exercise compliant } \\
\text { patients }\end{array}$ \\
\hline [99] & $\begin{array}{l}3 \text { week } \\
\text { intervention } \\
+6 \text { month } \\
\text { follow-up }\end{array}$ & $\begin{array}{l}\mathrm{N}=14(10 \text { men, } \\
4 \text { women, mean } \\
\text { age } 62.9 \pm 6.9 \\
\text { years }) \text { adults with } \\
\text { MetS }\end{array}$ & $\begin{array}{l}\text { Balanced diet corresponding to } \\
500 \text { Kcal deficit vs. their daily } \\
\text { energy expenditure (DEE) and } \\
\text { they exercised } 2 \text { to } 3 \text { hours per } \\
\text { day }\end{array}$ & $\begin{array}{l}\text { - Significant improvement in triglycerides, } \\
\text { total, LDL and HDL cholesterol, insulin, } \\
\text { leptin and adiponectin levels, CRP and pro- } \\
\text { inflammatory interleukines IL1, IL6 and TNF } \\
\alpha \text { were observed at } 3 \text { weeks } \\
\text { - No changes in cytokines were observed } \\
\text { - Changes were sustained at } 6 \text { months }\end{array}$ \\
\hline [100] & 1 year & $\begin{array}{l}\mathrm{N}=130 \text { (37\% } \\
\text { African } \\
\text { American) } \\
\text { severely obese } \\
\text { (class II or III) } \\
\text { adults without } \\
\text { diabetes }\end{array}$ & $\begin{array}{l}\text { Group1: diet + physical activity } \\
12 \text { months; group2: diet but } \\
\text { physical activity only from } 6 \\
\text { months onwards) }\end{array}$ & $\begin{array}{l}\text { Weight loss in group } 1 \text { was more significant } \\
\text { as compared to group } 2 \text { at } 6 \text { months } \\
(p=0.02) \\
\text { - Similar weight loss in both groups at } 12 \\
\text { months ( } p=0.25) \\
\text { - Reductions in Waist circumference, visceral } \\
\text { abdominal fat, hepatic fat content, blood } \\
\text { pressure, and insulin resistance in both groups }\end{array}$ \\
\hline [135] & Ongoing & $\begin{array}{l}N=4,600 \\
(5-40 \text { years })\end{array}$ & $\begin{array}{l}\text { Intensive (3-monthly) lifestyle } \\
\text { modification advice is superior } \\
\text { to a less-intensive ( } 12 \text { monthly; } \\
\text { control group) lifestyle } \\
\text { modification advice }\end{array}$ & $\begin{array}{l}\text { - Ongoing trail: follow up post } 5 \text { years of } \\
\text { intervention } \\
\text { - Aims to reduce the prevalence of DM, Pre- } \\
\text { Diabetes and MetS }\end{array}$ \\
\hline$[136]$ & $\begin{array}{l}\text { Short- } \\
\text { term }=12 \\
\text { weeks } \\
\text { and long- } \\
\text { term }=24 \\
\text { weeks }\end{array}$ & $\begin{array}{l}\mathrm{N}=66 \text { obese } \\
\text { adolescents ( } 41 \\
\text { girls and } 25 \text { boys; } \\
\text { BMI: } 35.62 \pm \\
\left.4.18 \mathrm{~kg} / \mathrm{m}^{2}\right)\end{array}$ & $\begin{array}{l}\text { Multidisciplinary lifestyle } \\
\text { therapy composed of } \\
\text { medical, dietary, exercise and } \\
\text { psychological programs }\end{array}$ & $\begin{array}{l}\text { - Long term therapy resulted in decreased } \\
\text { depression and binge eating symptoms, body } \\
\text { image dissatisfaction, and improved } \mathrm{QOL} \text { in } \\
\text { girls }(\mathrm{p}<0.05) \\
\text { - Reduced anxiety trait/state, symptoms of } \\
\text { binge eating and improvement in } \mathrm{QOL} \text { was } \\
\text { observed in boys }(\mathrm{p}<0.05)\end{array}$ \\
\hline [137] & 12 week & $\begin{array}{l}N=49 \text { (aged } 25- \\
80 \text { years) MED } \\
(n=19) ; \text { PED } \\
(n=25)\end{array}$ & $\begin{array}{l}\text { MED-Mediterranean-style, } \\
\text { low glycemic load diet group; } \\
\text { Phytochemical enriched diet } \\
\text { (PED)-Mediterranean diet + } \\
\text { phytochemicals }\end{array}$ & $\begin{array}{l}\text { - Weight loss was achieved in both groups } \\
\text { - More significant reductions in the cholesterol } \\
\text { levels, triglycerides, cholesterol/HDL and } \\
\text { TG/HDL ratio was observed in PED group } \\
(p<0.05) \text { compared to MED } \\
\text { - Increased HDL( }<<0.05) \text {, decreased TG/ } \\
\text { HDL }(p<0.01) \text {, and resolution of more } \\
\text { number of patients }(43 \%) \text { from MetS was } \\
\text { seen only in the PED group }\end{array}$ \\
\hline [138] & 12 weeks & $\begin{array}{l}\mathrm{N}=59(\mathrm{n}=20 \mathrm{WL} \\
\mathrm{n}=20 \mathrm{WL}+\mathrm{EX} \\
\mathrm{n}=19 \text { control) }\end{array}$ & $\begin{array}{l}\text { dietary weight loss }(W L \text {, } \\
n=20) \text {; dietary weight loss and } \\
\text { moderate-intensity aerobic } \\
\text { exercise }(W L+E X, n=20) \text {; no } \\
\text { treatment }(n=19)\end{array}$ & $\begin{array}{l}\text { Decrement in body weight }(P<0.001) \text {, } \\
\text { Resting SNS activity }(p<0.01) \text {, muscle } \\
\text { sympathetic nerve activity }(p<0.01) \text { was } \\
\text { observed in both } W L \text { and } W L+E X \text { group } \\
\text { Increment in fitness levels were seen only in } \\
\text { WL+EX group }(P<0.001)\end{array}$ \\
\hline
\end{tabular}

Table IV. Role of Lifestyle interventions (RCTs) in combating MetS and its components

$\mathrm{ALT}=$ Alanine Amino Transferase; $\mathrm{BMI}=$ Body Mass Index; $\mathrm{CRP}=\mathrm{C}$ Reactive Protein; DEE = Daily Energy

Expenditure; $\mathrm{DM}=$ Diabetes Mellitus; $\mathrm{EX}=$ Exercise; $\mathrm{HDL}=$ High Density Lipoprotein; IL-1 = Interleukin 1;

IL-2 = Interleukin 2; LDL = Low Density Lipoprotein; MetS = Metabolic Syndrome; NAFLD = Non-Alcoholic

Fatty Liver Disease; PED = Phytochemical Enriched Diet; $\mathrm{QOL}=$ Quality of Life; SNS = Sympathetic Nervous System; TG $=$ Triglycerides; TNF $\alpha=$ Tumor Necrosis Factor $\alpha ; \mathrm{WC}=$ Waist Circumference; $\mathrm{WL}=$ Weight Loss 
A therapeutic lifestyle program (TLM) is the most sought after way of tackling the syndrome. A hospital based intervention consisting of a low calorie diet and regular aerobic physical activity was conducted for 8 weeks in women $(n=44)$ with MetS. Significant decrease in all MetS components except HDL-C, along with complete amelioration of the syndrome in $25 \%$ of women was observed [104]. Impact of TLM was also assessed among the rural women $(n=32)$ with MetS who were randomized to a 4 week intervention consisting of health screening, education, exercise, diet and counselling, while a basic education booklet on MetS was provided to the control group. Significant reduction in the body weight, waist circumference, triglyceride levels, and positive behaviour change was noticed in the intervention group compared to the control group $(\mathrm{p}<0.01)$. A positive time effect was noticed with the intervention group which resulted in decrement in the systolic blood pressure, fasting glucose, and LDL levels, and increment in the HDL levels, thus, substantiating the role of a TLM intervention in MetS improvement [105]. Another lifestyle intervention encompassing healthy diet evaluating the metabolic and vascular changes that occur with the syndrome was carried out. Seventy five adults with MetS (30-55 years) were randomized to a 10,000-steps-a-day exercise program + healthy, no-sugar diet; a 3-times-a-week fitness (>75\% peak VO2) program + healthy, no-sugar diet; and a 1-hourwalking-a-day program + a tailored low-fat diet for 12 weeks. Significant increase in Flow Mediated Vasodilation and decrease in arterial pressure was maximum in the high intensity, no sugar group $(\mathrm{p}=0.036)$, wherein, arterial pressure decrease $(\mathrm{p}=0.0001)$ and weight loss $(\mathrm{p}=0.0001)$ was maintained post 1 year [106]. Similarly, a pilot study comprising 150 minutes of regular exercise, 200-300 kcal reduced daily diet for weight reduction, individual psycho-behavioural counselling based on Trans theoretical model and telephone coaching for behavioural modification, on 43 Korean adults with Type2 $\mathrm{DM}$ and MetS proved to be beneficial $(\mathrm{p}<0.05)$ leading to better glycemic control, lessened CVD risk, and depression [107]. So, weight reduction seems to be a good strategy to target as a component of the syndrome that has the potential resulting in improvement of the other components of the syndrome.

\section{Interventions at the genetic level}

Role of genetics in the pathobiology of the syndrome, though small, is extremely significant [108]. Since MetS is an outcome of both environmental as well as genetic factors, a dietary intervention (12 weeks) was undertaken in women $(n=24)$ with the syndrome, to observe any change in the expression of LDL receptor and 3-hydroxy-3-methylglutarylcoenzymeA (HMG-CoA) reductase genes. Significant decreases in WC $(\mathrm{p}<0.001)$, plasma triglycerides $(\mathrm{p}<0.05)$, systolic blood pressure $(\mathrm{p}<0.05), \mathrm{LDL}-$ $\mathrm{C}(\mathrm{p}<0.01)$, plasma insulin $(\mathrm{p}<0.001)$, plasma TNF $\alpha(\mathrm{p}<0.01)$, and homeostatic model assessment score for insulin resistance $($ HOMA-IR) $(\mathrm{p}<0.001)$ were observed post-intervention. Though no change in the LDL cholesterol gene expression was detected, reduction in HMG-CoA reductase gene expression $(\mathrm{p}<0.001)$ was observed [76]. This is an important finding as HMG-CoA reductase is the key regulatory gene in cholesterol synthesis that can ultimately lead to lowered very low density lipoprotein (VLDL) levels and correspondingly decrease LDL cholesterol. Modulation in the genetic expression of other genes have also been observed with a dietary intervention focusing on $\mathrm{MeD}$ in patients with MetS $(\mathrm{n}=20)$ and high CVD risk $(\mathrm{n}=49)$. It resulted in changes in the genetic expression of cyclooxygenases 1 and 2, monocyte chemotactic protein 1, low-density lipoprotein (LDL) receptor-related gene, and pro-inflammatory genes. So, alongside environmental factors, an understanding of the genetic factors is also essential to customize treatment strategies [109].

\section{Inflammation: an important component of intervention strategy}

Several contributory factors such as abdominal obesity, dyslipidemia, impaired glucose tolerance, high blood pressure and prothrombotic state lead to the development of MetS [110]. Studies relating low-grade inflammation to MetS have been reported, with various biomarkers like increased C-reactive protein (CRP), increased IL-6, increased TNF, decreased IL-10, decreased adiponectin, increased 
leptin, increased Serum Amyloid A (SAA), increased resistin and increased Plasminogen Activator Inhibitor-1(PAI-1) being responsible for it [111]. Chronic low-grade inflammation is associated with insulin resistance. One of the main components of the inflammatory process is cytokines, particularly, IL-1, TNF and IL-6, of which IL-6 is the central mediator of inflammatory response. Its relationship with insulin, mediated through adiposity, links it to MetS. Another proinflammatory cytokine viz. TNF, secreted to a large extent by adipocytes, is an important regulator of insulin sensitivity, which decreases with weight loss. Besides these, other markers such as adiponectins are also associated with MetS [111]. Interventions to target MetS have shown an impact on its markers such as circulating adiponectin. Forty four obese adolescent obese girls (13-15 years), who were randomized to a lifestyle plus exercise intervention group (LIFE+EX, $n=22$ ) or control (CON, $n=22$ ) for 12 weeks, resulted in improvements in body composition, waist circumference, waist-to-hip ratio, and significant reductions in blood pressure, triglycerides, LDL levels, glucose, insulin, HOMA-IR, CRP, and leptin compared to the controls. However, no change was observed in the circulating adiponectin levels [112]. Metabolic alterations associated with MetS particularly, decrement in the levels of metabolic variables and CRP values were gauged for their affiliation with diet/exercise variation. In a prospective randomized control trial of 169 cases and 166 controls [113], exercise levels were inversely associated with CRP ( $<<0.001)$, as fibre intake was with fasting glucose $(\mathrm{p}<0.001)$, independent of weight reduction. Changes in the C-reactive protein with either a low fat diet or physical activity or both was demonstrated among men $(n=149)$ and post menopausal women $(n=125)$ in a 1 year RCT. Significant changes in CRP in both diet + physical activity group was more than physical activity group only $(\mathrm{p}=0.02)$. Any diet treatment with or without physical activity also had greater CRP change than the control $(p=0.001)$, thus, demonstrating the efficacy of a low fat diet for reduction of the syndrome [94].

A recent review proposed the role of interleukin-18 (IL-18) in the pathogenesis of diabetes and MetS, as a predictor of cardio-vascular events and mortality. IL-18 results in induction of inflammatory reactions being present in the adipose tissue, atherosclerotic plaque and in the muscle tissue, therefore, can act as a marker of chronic low-grade inflammation [114]. The association of MetS with beta 3-adrenergic receptor (ADRB3) Trp64Arg polymorphism was examined in 36 male employees with MetS (average age, $49 \pm 6$ years old) undergoing a three month intervention. There was $53.8 \%$ improvement in the MetS post intervention in participants with ADRB3 Trp64Arg polymorphism, supporting its role in influencing the syndrome coupled with an exercise-based intervention program [115]. The relationship of inflammatory markers and their possible role in the pathogenesis of MetS have a unique prospect in combating the syndrome as various repercussions associated with the syndrome are correlated with them. Development of cost-effective strategies for evaluation of these markers needs to be done so that they can be used for prevention as well as treatment of the syndrome.

\section{Early intervention: need of the hour}

Early interventions have a better potential of targeting the syndrome than doing it at a later stage, where much improvement cannot occur. A multidisciplinary school based intervention can be a promising strategy [116]. This was carried out in overweight and obese adolescents $(n=37$ intervention group; $\mathrm{n}=39$ control; age: $17.3 \pm 1.3$ years; BMI: $29.5 \pm 3.7 \mathrm{~kg} / \mathrm{m}^{2}$ ) who were encouraged to adopt a healthy lifestyle, coupled with consultations from dieticians and physiotherapists, and a free membership to a nearby fitness centre. After 6 months of intervention significant weight loss $(\mathrm{p}<0.001)$, change in BMI $(\mathrm{p}<0.001)$, decrement in WC $(\mathrm{p}=0.011)$ and fasting glucose $(\mathrm{p}=0.005)$ was observed compared to the control group, thus, guaranteeing the usefulness of a multi disciplinary intervention program [117]. Rarity of lifestyle interventions in obese children leads to the possibility of development of MetS in future. Obesity and overweight in children can thus, have serious ramifications if not controlled sooner enough projecting to high risk for development of MetS and subsequent CVD in adulthood $[118,119]$. A lifestyle intervention with obese children ( $n=288$ intervention group; $n=186$ control group) led to a 
significant decrease in BMI, WC, oral glucose tolerance test (OGTT) values, blood pressure and MetS prevalence in the intervention group as compared to controls [120]. A rigorous lifestyle intervention, in which a high-fibre, low-fat diet in a 2-week residential program where food was provided ad libitum, and daily aerobic exercise was performed, was carried out in 16 overweight and obese subjects. Post 2 weeks of intervention, significant decrement in insulin level $(\mathrm{p}<0.01)$, HOMA insulin level $(\mathrm{p}<0.05)$, body weight $(\mathrm{p}<0.01)$, total cholesterol $(\mathrm{p}<0.01), \mathrm{LDL}(\mathrm{p}<0.01)$, triglycerides $(\mathrm{p}<0.01), \mathrm{LDL} / \mathrm{HDL}$ ratio $(\mathrm{p}<0.01)$, systolic blood pressure $(\mathrm{p}<0.001)$ and diastolic blood pressure $(\mathrm{p}=0.01)$; however, no change was observed in HDL-C levels. Of the 7 patients who were diagnosed with MetS, the syndrome reversed in all of them [121].

\section{Evidence generation from intervention trials: development of public policies}

For development and improvement of the public policies, evidence generated through intervention trials holds the key. However, sustainability is an important issue with respect to most interventional studies which falter in the long run because of poor compliance and low cohesion rates [122-125]. Restrictions in diet only serve the purpose as long as they aren't overtly limiting; as chances of rebound and the intensification of the appetite with reference to too many restricted foods isn't inevitable [126]. It holds the key to behaviour change in confronting MetS. Though, intensive, individualized lifestyle intervention programs are the most appropriate step for increasing sustainability; cost and time are limited [127]. A 16 week group based intervention, economical in terms of cost and time was formulated for 153 obese/overweight individuals focusing on dietary and physical activity information, behavioural self management tools, food label reading, supermarket tour and cooking, exercise sessions and peer group support. Usefulness of various components of the intervention was reported by participants in the intervention group compared to controls. Such programs bring out the need of active training in lifestyle modification rather than passive provision of guidelines in the form of a booklet. Weight loss and weight maintenance are two important concepts that go hand in hand. Weight loss alone can't be the criteria for tackling MetS, because if the lost weight is not sustained chances of rebounding is high [128]. Weight loss maintenance in an intervention ( $\mathrm{n}=14$ males; 4 females) resulted stable energy balance affected sympathetic nervous system activity leading to decrement in nor epinephrine spill over rate $(\mathrm{p}=0.004)$, muscle sympathetic nerve activity $(\mathrm{p}<0.001)$, and plasma rennin activity $(\mathrm{p}=0.007)$, and increment in baroreflex sensitivity $(\mathrm{p}=0.005)$. Compliance and adherence are two substantial perspectives that need to be addressed whenever lifestyle intervention programs are implemented for syndrome's reduction. Though there have been studies regarding the implementation of these programs, sustainability is the issue that has been neglected often. Therefore, approaches to increase sustainability are required for combating the syndrome effectively [129]. With substantial health consequences, it becomes all the more important that MetS needs to be targeted, and physical activity along with diet improvement is one such measure that has the ability to attenuate the syndrome if performed methodically $[96,128,130]$.

\section{Conclusion}

With westernization of the worldwide dietary pattern, MetS is reaching epidemic proportions, wherein, diet and lifestyle interventions are regarded as the first line of defence for combating it [131]. The consequences of globalization and industrialization are the emergence of lifestyle related NCDs contributed by unhealthy dietary patterns, lack of physical activity and smoking as well as alcohol abuse. 
Future directions for research

Future studies should be undertaken focusing on carrying out interventions (diet and lifestyle) among young adults in whom the prevalence of the syndrome might be low but have a great potential of developing it in future if no action is taken early. Development of appropriate strategies to increase the sustainability of these interventions must be accomplished to combat the syndrome. The diagnosis and severity of the syndrome should be based on uniform diagnostic criteria considering population, country and ethnicity. Since, there are a multitude of risk factors that eventually lead to MetS, longitudinal studies should be conducted to understand the interaction among these factors. Future studies should concentrate on determining a suitable dietary composition that could be considered as a template for alleviation of the syndrome. Special attention needs to be drawn on genetics as well as inflammatory markers such as IL, CRP, adrenagic receptors etc, which can be used in the development of cost-effective strategies for prevention and treatment of MetS.

With only a handful of people following the healthy diet and lifestyle, majority still fall in the bracket of those with compromised diet and lifestyle, burdening the health services [95]. Socio economic changes and eventually globalization has led to transformation in the society. This has led to alterations in the dietary habits eventually resulting in nutrition transition [132]. A first line intervention targeting MetS involves dietary and lifestyle modification with regular physical activity over a period of time. However, improvement in MetS parameters can only be maintained when these modifications can be sustained. This requires multiple follow up sessions post-intervention rather than one counselling ses-

\section{The review in brief}

Clinical question Dietary and lifestyle modification has been underlined as the first treatment to combat Metabolic Syndrome by AHA. The present review analyzes the role of dietary and lifestyle modification as an effective strategy to reduce the syndrome.

Type of review Narrative

Search of the Medline, PubMed (National Library of Medicine, Bethesda, MD, USA), Cochrane Library, Science literature Direct and Google Scholar search using the following keywords: Metabolic Syndrome, diet, lifestyle, Mediterranean diet, intervention, insulin resistance, obesity, non- communicable diseases, hypertension, HDL, triglycerides, inflammation, genetics, CRP

Conclusions The present review concludes that:

- MetS is a complex entity that is a result of multitude of factors.

- Dietary and lifestyle modification is the first line of treatment for prevention of the syndrome.

- Mediterranean and low calorie diets have the potency to cause a resultant decrease in various components of MetS.

- Regular physical activity along with diet improvement has the ability to attenuate the syndrome if performed methodically.

- Weight reduction resulting from dietary and lifestyle modification has proven beneficial in combating the syndrome.

- Alongside environmental factors, an understanding of the genetic factors and inflammatory markers is also essential to customize treatment strategies.

- Early interventions have a better potential of targeting the syndrome than doing it at a later stage, where much improvement cannot occur.

Limitations Though various studies involving dietary and lifestyle modification have shown benefits by resulting in the improvement of various components of the syndrome, the emphasis needs to be laid on carrying out research that ultimately looks at the sustainability and compliance with such interventions, in order to show their efficacy on a long-term basis. 
sion involving the use of several behavioural techniques to improve compliance [133]. For development and improvement of the public policies, evidence generated through intervention trials holds the key. Therefore, dietary and lifestyle modification in continuum is required to overcome MetS holistically.

\section{References}

1. Popkin BM, Adair LS, Ng SW. Global nutrition transition and the pandemic of obesity in developing countries. Nutr Rev 2012; 70: 3-21; http://dx.doi.org/10.1111/j.1753-4887.2011.00456.x

2. Misra A, Singhal N, Sivakumar B, et al. Nutrition transition in India: Secular trends in dietary intake and their relationship to diet-related non-communicable diseases. J Diabetes 2011; 3: 278-92; http://dx.doi.org/10.1111/j.1753-0407.2011.00139.x

3. Misra A. Overnutrition and nutritional deficiency contribute to metabolic syndrome and atherosclerosis in Asian Indians. Nutrition 2002; 18: 702-3; http://dx.doi.org/10.1016/S08999007(02)00818-3

4. Reddy KS. Cardiovascular diseases in the developing countries: dimensions, determinants, dynamics and directions for public health action. Public Health Nutr 2002; 5: 231-7; http://dx.doi. org/10.1079/PHN2001298

5. Murray CJL, Lopez AD. The global burden of disease. Boston: Harvard School of Public Health, 1996

6. World Health Organization. The World Health Report: life in the 21st century: A vision for all. Geneva: World Health Organization, 1998

7. Sicree R, Shaw J, Zimmet P. Diabetes and impaired glucose tolerance in India. In: Gan D. Diabetes atlas, $3^{\text {rd }}$ ed. Kortrijik (Hevle), Belgium: International Diabetes Federation 2006; 15-103

8. Pritchett AM, Foreyt JP, Mann DL. Treatment of the Metabolic Syndrome: The Impact of Lifestyle Modification. Curr Atheroscler Rep 2005; 7: 95-102; http://dx.doi.org/10.1007/s11883-005-0030-4

9. Modan M, Halkin H, Almog S, et al. Hyperinsulinaemia - A link between hypertension, obesity and glucose intolerance. J Clin Invest 1985; 75: 809-17; http://dx.doi.org/10.1172/JCI111776

10. Ferrannini E, Haffner M, Mitchell BD, et al. Hyperinsulinaemia: the key feature of a cardiovascular and metabolic syndrome. Diabetologia 1991; 34: 416-22; http://dx.doi.org/10.1007/BF00403180

11. Reaven GM. Role of insulin resistance in human disease. Diabetes 1988; 37: 1595-607; http:// dx.doi.org/10.2337/diab.37.12.1595

12. National Cholesterol Education Program (NCEP) Expert Panel on Detection, Evaluation, and Treatment of High Blood Cholesterol in Adults (Adult Treatment Panel III). Third Report of the National Cholesterol Education Program (NCEP) Expert Panel on Detection, Evaluation, and Treatment of High Blood Cholesterol in Adults (Adult Treatment Panel III) final report. Circulation 2002; 106: 3143-421; http://circ.ahajournals.org/content/106/25/3143.citation

13. Do Carmo I, Dos Santos O, Camolas J, et al. Overweight and obesity in Portugal: National prevalence in 2003-2005. Obes Rev 2008; 9: 11-9; http://dx.doi.org/10.1111/j.1467-789X.2007.00422.x

14. Hollman G, Kristenson M. The prevalence of the metabolic syndrome and its risk factors in a middle-aged Swedish population-mainly a function of overweight? Eur J Cardiovasc Nurs 2008; 7: 21-6; http://dx.doi.org/10.1016/j.ejcnurse.2007.05.003

15. Hillier TA, Fagot-Campagna A, Eschwege E, et al. Weight change and changes in the metabolic syndrome as the French population moves towards overweight: The D.E.S.I.R. cohort. Int J Epidemiol 2006; 35: 190-6; http://dx.doi.org/10.1093/ije/dyi281

16. Ervin RB. Prevalence of Metabolic Syndrome among Adults 20 Years of Age and Over, by Sex, Age, Race and Ethnicity, and Body Mass Index: United States, 2003-2006. National Health Statistics Reports. Hyattsville, MD: National Center for Health Statistics 2009, No. 13 
17. Kanjilal S, Shanker J, Rao VS, et al. Prevalence and component analysis of metabolic syndrome: An Indian atherosclerosis research study perspective. Vasc Health Risk Manag 2008; 4: 189-97; http:// dx.doi.org/10.2147/VHRM.S2279

18. Misra A, Khurana L. Obesity and the Metabolic Syndrome in Developing Countries. J Clin Endocrinol Metab 2008; 93: S9-S30; http://dx.doi.org/10.1210/jc.2008-1595

19. Misra A, Misra R. Asian Indians and insulin resistance syndrome: Global perspective. Metab Syndr Relat Disord 2003; 1: 277-85; http://dx.doi.org/10.1089/1540419031361390

20. Misra A, Pandey RM, Devi JR, et al. High prevalence of diabetes, obesity and dyslipidaemia in urban slum population in northern India. Int J Obes Relat Metab Disord 2001; 25: 1722-9

21. Carr DB, Utzschneider KM, Hull RL, et al. Intra-abdominal fat is a major determinant of the National Cholesterol Education Program Adult Treatment Panel III criteria for the metabolic syndrome. Diabetes 2004; 53: 2087-94; http://dx.doi.org/10.2337/diabetes.53.8.2087

22. Park YW, Zhu S, Palaniappan L, et al. The metabolic syndrome: prevalence and associated risk factor findings in the US population from the Third National Health and Nutrition Examination Survey, 1988-1994. Arch Intern Med 2003; 163: 427-36; http://dx.doi.org/10.1001/archinte.163.4.427

23. Lemieux I, Pascot A, Couillard C, et al. Hypertriglyceridemic waist: a marker of the atherogenic metabolic triad (hyperinsulinemia; hyperapolipoprotein B; small, dense LDL in men? Circulation 2000; 102: 179-84; http://dx.doi.org/10.1161/01.CIR.102.2.179

24. Gustat J, Srinivasan SR, Elkasabany A, et al. Relation of self-rated measures of physical activity to multiple risk factors of insulin resistance syndrome in young adults: the Bogalusa Heart Study. J Clin Epidemiol 2002; 55: 997-1006; http://dx.doi.org/10.1016/S0895-4356(02)00427-4

25. Ford ES, Giles WH, Dietz WH. Prevalence of the metabolic syndrome among US adults: Findings from the third National Health and Nutrition Examination Survey. JAMA 2002; 287: 356-9; http:// dx.doi.org/10.1001/jama.287.3.356

26. Apridonidze T, Essah PA, Iuorno MJ, et al. Prevalence and characteristics of the metabolic syndrome in women with polycystic ovary syndrome. J Clin Endocrinol Metab 2004; 90: 1929-35; http:// dx.doi.org/10.1210/jc.2004-1045

27. Misra A, Vikram NK. Factors, definitions, predictive value \& Asian Indian ethnicity: Complexities of the metabolic syndrome. Indian J Med Res 2008; 127: 293-6

28. Kamble P, Deshmukh PR, Garg N. Metabolic Syndrome in adult population of rural Wardha, Central India. Indian J Med Res 2010; 132: 701-5

29. Prabhakaran D, Chaturvedi V, Shah P, et al. Differences in the prevalence of metabolic syndrome in urban and rural India: a problem of urbanization. Chronic Illn 2007; 3: 8-19; http://dx.doi. org/10.1177/1742395307079197

30. Mohan V, Gokulakrishnan K, Deepa R, et al. Association of physical inactivity with components of metabolic syndrome and coronary artery disease; the Chennai Urban Population Study (CUPS no. 15). Diabetic Med 2005; 22: 1206-11; http://dx.doi.org/10.1111/j.1464-5491.2005.01616.x

31. Yeolekar ME. Coronary artery disease in Asian Indians. J Postgrad Med 1998; 44: 26-8; http://www. jpgmonline.com/text.asp?1998/44/1/26/382

32. Misra A, Misra R, Wijesuriya M, et al. The metabolic syndrome in South Asians: Continuing escalation \& possible solutions. Indian J Med Res 2007; 125: 345-54

33. Sharifi F, Mousavinasab SN, Saeini M, et al. Prevalence of Metabolic Syndrome in an Adult Urban Population of the West of Iran. Exp Diabetes Res 2009: 5; http://dx.doi.org/10.1155/2009/136501

34. He Y, Jiang B, Wang J, et al. Prevalence of the metabolic syndrome and its relation to cardiovascular disease in an elderly Chinese population. J Am Coll Cardiol 2006; 47: 1588-94; http://dx.doi. org/10.1016/j.jacc.2005.11.074

35. Adams RJ, Appleton S, Wilson DH, et al. Population comparison of two clinical approaches to the metabolic syndrome: implications of the new International Diabetes Federation consensus definition. Diabetes Care 2005; 28: 2777-9; http://dx.doi.org/10.2337/diacare.28.11.2777 
36. Gupta R, Sarna M, Thanvi J, et al. High prevalence of multiple coronary risk factors in Punjabi Bhatia community: Jaipur Heart Watch-3. Indian Heart J 2004; 56: 646-52

37. Hu FB, Meigs JB, Li TY, et al. Inflammatory markers and risk of developing type 2 diabetes in women. Diabetes 2004; 53: 693-700; http://dx.doi.org/10.2337/diabetes.53.3.693

38. Mangat C, Goel NK, Walia DK, et al. Metabolic Syndrome: a challenging health Issue in highly urbanized Union Territory of North India. Diabetol Metab Syndr 2010; 2: 19

39. Smith C, Essop MF. Gender differences in metabolic risk factor prevalence in a South African student population. Cardiovasc J Africa 2009; 20: 178-82

40. Regitz-Zagroek V, Lehmkuhl E, Mahmoodzadeh S. Gender aspects of the role of the metabolic syndrome as a risk factor for cardiovascular disease. Gen Med 2007; 4: S162-77; http://dx.doi. org/10.1016/S1550-8579(07)80056-8

41. Sarkar S, Das M, Mukhopadhyay B, et al. High prevalence of metabolic syndrome and its correlates in two tribal populations of India and the impact of urbanization. Indian J Med Res 2006; 123: 679-86

42. Ramachandran A, Snehalatha C, Satyavani K, et al. Metabolic syndrome in urban Asian Indian adults - a population study using modified ATP-III criteria. Diabetes Res Clin Pract 2003; 60: 199204; http://dx.doi.org/10.1016/S0168-8227(03)00060-3

43. Perel P, Langenberg C, Ferrie J, et al. Household wealth and the metabolic syndrome in the Whitehall II study. Diabetes Care 2006; 29: 2694-700; http://dx.doi.org/10.2337/dc06-0022

44. Dallongeville J, Cottel D, Ferrieres J, et al. Household income is associated with the risk of metabolic syndrome in a sex-specific manner. Diabetes Care 2005; 28: 409-15; http://dx.doi.org/10.2337/ diacare.28.2.409

45. Du S, Mroz TA, Zhai F, et al. Rapid income growth adversely affects diet quality in China - Particularly for the poor! Soc Sci Med 2004; 59: 1505-15; http://dx.doi.org/10.1016/j.socscimed.2004.01.021

46. Brunner EJ, Marmot MG, Nanchahal K, et al. Social inequality in coronary risk: Central obesity and the metabolic syndrome. Evidence from the Whitehall II study. Diabetologia 1997; 40: 134149; http://dx.doi.org/10.1007/s001250050830

47. Deepa M, Farooq S, Datta M, et al. Prevalence of metabolic syndrome using WHO, ATP-III and IDF definitions in Asian Indians: the Chennai Urban Rural Epidemiology Study (CURES-34). Diabetes 2006; 23: 127-34; http://dx.doi.org/10.1002/dmrr.658

48. Florez H, Silva E, Fernandez V, et al. Prevalence and risk factors associated with the metabolic syndrome and dyslipidemia in White, Black, Amerindian and Mixed Hispanics in Zulia State, Venezuela. Diabetes Res Clin Pract 2005; 69: 63-77; http://dx.doi.org/10.1016/j.diabres.2004.11.018

49. Al-Lawati JA, Mohammed AJ, Al-Hinai HQ, et al. Prevalence of the metabolic syndrome among Omani adults. Diabetes Care 2003; 26: 1781-5; http://dx.doi.org/10.2337/diacare.26.6.1781

50. Reddy KS, Prabhkaran D, Chaturvedi V, et al. Methods for establishing a surveillance system for cardiovascular diseases in Indian industrial populations. Bull World Health Organ 2006; 84: 46169; http://dx.doi.org/10.1590/S0042-96862006000600015

51. Rosengren A, Anderson K, Wilhelmsen L. Risk of coronary heart disease in middle-aged male bus and tram drivers compared to men in other occupations: A prospective study. Int J Epidemiol 1991; 20: 82-7; http://dx.doi.org/10.1093/ije/20.1.82

52. León Latre M, Andrés EM, Cordero A, et al. Relationship between metabolic syndrome and ischemic heart disease mortality in Spain. Rev Esp Cardiol 2009; 62: 1469-72; http://dx.doi.org/10.1016/ S1885-5857(09)73544-3

53. Taraghi Z, Ilali E. Screening of Hypertension in truck drivers in Mazandaran. HAYAT 2004; 10: 63-70

54. Grundy SM, Cleeman JI, Daniels SR, et al. Diagnosis and Management of the Metabolic Syndrome: An American Heart Association/National Heart, Lung, and Blood Institute Scientific Statement. Circulation 2005; 112: 2735-52; http://dx.doi.org/10.1161/CIRCULATIONAHA.105.169404 
55. AHA Scientific Statement. Grundy SM, Cleeman JI, Daniels SR, et al. Diagnosis and Management of the Metabolic Syndrome: An American Heart Association/National Heart, Lung, and Blood Institute Scientific Statement: Executive Summary. Circulation 2005; 112: e285-e90; http://dx.doi. org/10.1161/CIRCULATIONAHA.105.169405

56. Buckland G, Salas-Salvadó J, Roure E, et al. Socio-demographic risk factors associated with metabolic syndrome in a Mediterranean population. Public Health Nutr 2008; 11: 1372-8; http://dx.doi. org/10.1017/S1368980008003492

57. Noto D, Barbagallo CM, Cefalù AB, et al. The metabolic syndrome predicts cardiovascular events in subjects with normal fasting glucose: Results of a 15 years follow-up in a Mediterranean population. Atherosclerosis 2008; 197: 147-53; http://dx.doi.org/10.1016/j.atherosclerosis.2007.03.005

58. Barbato A, Cappuccio FP, Folkerd EJ, et al. Metabolic syndrome and renal sodium handling in three ethnic groups living in England. Diabetologia 2004; 47: 40-6; http://dx.doi.org/10.1007/ s00125-003-1260-z

59. Chandalia M, Abate N, Garg A, et al. Relationship between generalized and upper body obesity to insulin resistance in Asian Indian men. J Clin Endocrinol Metab 1999; 84: 2329-35; http://dx.doi. org/10.1210/jc.84.7.2329

60. World Health Organization Western Pacific Region, International Association for the Study of Obesity, International Obesity Task Force: The Asia-Pacific Perspective: Redefining Obesity and its Treatment. Sydney: Health Communications Australia, 2000

61. Ronnemaa T, Ronnemaa EM, Puukka P, et al. Smoking is independently associated with high plasma insulin levels in non-diabetic men. Diabetes Care 1996; 19: 1229-32; http://dx.doi.org/10.2337/ diacare.19.11.1229

62. Facchini FS, Hollenbeck CB, Jeppesen J, et al. Insulin resistance and cigarette smoking. Lancet 1992; 339: 1128-30

63. Freiberg MS, Cabral HJ, Heeren TC, et al. Alcohol consumption and the prevalence of the metabolic syndrome in the US: A cross sectional analysis of data from the Third National Health and Nutrition Examination Survey. Diabetes Care 2004; 27: 2954-59; http://dx.doi.org/10.2337/ diacare.27.12.2954

64. Vernay M, Balkau B, Moreau JG, et al. DESIR study group. Alcohol consumption and insulin resistance syndrome parameters. Associations and evolutions in a longitudinal analysis of the French DESIR cohort. Ann Epidemiol 2004; 14: 209-14; http://dx.doi.org/10.1016/S1047-2797(03)00131-5

65. Yoon YS, Oh SW, Baik HW, et al. Alcohol consumption and the metabolic syndrome in Korean adults: the 1998 Korean National Health and Nutrition Examination Survey. Am J Clin Nutr 2004; 80: $217-24$

66. Djousse L, Ellison RC, Beiser A, et al. Alcohol consumption and risk of ischemic stroke: the Framingham Study. Stroke 2002; 33: 907-12; http://dx.doi.org/10.1161/hs0402.105245

67. Hotamisligil GS. Inflammation and metabolic disorders. Nature 2006; 444: 860-7; http://dx.doi. org/10.1038/nature05485

68. Hanley AJ, Festa A, D’Agostino RB Jr, et al. Metabolic and inflammation variable clusters and prediction of type 2 diabetes: factor analysis using directly measured insulin sensitivity. Diabetes 2004; 53: 1773-81; http://dx.doi.org/10.2337/diabetes.53.7.1773

69. Poulsen P, Vaag A, Kyvik K, et al. Genetic versus environmental aetiology of the metabolic syndrome among male and female twins. Diabetologia 2001; 44: 537-43; http://dx.doi.org/10.1007/ s001250051659

70. Zabaneh D, Balding DJ. A Genome-Wide Association Study of the Metabolic Syndrome in Indian Asian Men. Diabetes Care 2010; 5: 1-6; http://dx.doi.org/10.1371/journal.pone.0011961

71. Nobili V, Vizzutti F, Arena U, et al. Accuracy and reproducibility of transient elastography for the diagnosis of fibrosis in pediatric nonalcoholic steatohepatitis. Hepatology 2008; 48: 442-8; http:// dx.doi.org/10.1002/hep.22376 
72. Hales CN, Ozanne SE. Fetal and early postnatal growth restriction lead to diabetes, the metabolic syndrome and renal failure. Diabetologia 2003; 46: 1013-9; http://dx.doi.org/10.1007/s00125-003-1131-7

73. Laaksonen DE, Niskanen L, Nyyssönen K, et al. C-reactive protein and the development of the metabolic syndrome and diabetes in middle-aged men. Diabetologia 2004; 47: 1403-10; http:// dx.doi.org/10.1007/s00125-004-1472-x

74. Krishnaswamy K. Evolutionary aspects of diets in the context of current chronic diseases. NFI Bulletin 2011; 33

75. Landaeta-Díaz L, Fernández JM, Da Silva-Grigoletto M, et al. Mediterranean diet, moderate-tohigh intensity training and health-related quality of life in adults with metabolic syndrome. Eur J Prev Cardiol Eur J Prev Cardiol 2013; 20: 555-64; http://dx.doi.org/10.1177/2047487312445000

76. Jones JL, Fernandez ML, McIntosh MS, et al. A Mediterranean-style low-glycemic-load diet improves variables of metabolic syndrome in women, and addition of a phytochemical-rich medical food enhances benefits on lipoprotein metabolism. J Clin Lipidol 2011; 5: 188-96; http://dx.doi. org/10.1016/j.jacl.2011.03.002

77. Rumawas ME, Meigs JB, Dwyer JT, et al. Mediterranean-style dietary pattern, reduced risk of metabolic syndrome traits, and incidence in the Framingham Offspring Cohort. Am J Clin Nutr 2009; 90: 1608-14; http://dx.doi.org/10.3945/ajcn.2009.27908

78. Galland L. Diet and inflammation. Nutr Clin Pract 2010; 25: 634-40; http://dx.doi. org/10.1177/0884533610385703

79. Michalsen A, Lehmann N, Pithan C, et al. Mediterranean diet has no effect on markers of inflammation and metabolic risk factors in patients with coronary artery disease. Eur J Clin Nutr 2006; 60: 478-85; http://dx.doi.org/10.1038/sj.ejcn.1602340

80. Serra-Majem Ll, Ngo J, Ribas L, et al. Olive oil and the Mediterranean diet: beyond the rhetoric. Eur J Clin Nutr 2003; 57: 2S-7S; http://dx.doi.org/10.1038/sj.ejcn.1601801

81. Shenoy SF, Poston WSC, Reeves RS, et al. Weight loss in individuals with metabolic syndrome given DASH diet counseling when provided a low sodium vegetable juice: A randomized controlled trial. Nutrition J 2010; 9: 8-19; http://dx.doi.org/10.1186/1475-2891-9-8

82. Pettman TL, Buckley JD, Misan GMH, et al. Health benefits of a 4-month group-based diet and lifestyle modification program for individuals with metabolic syndrome. Obes Res Clin Prac 2009; 3: 221-35; http://dx.doi.org/10.1016/j.orcp.2009.06.002

83. Esposito K, Marfella R, Ciotola M, et al. Effect of a Mediterranean style diet on endothelial dysfunction and markers of vascular inflammation in the metabolic syndrome: a randomized trial. JAMA 2004; 292: 1440-6; http://dx.doi.org/10.1001/jama.292.12.1440

84. Babio N, Bullo M, Basora J, et al. Nureta-PREDIMED Investigators. Adherence to the Mediterranean diet and risk of metabolic syndrome and its components. Nutr Metab Cardiovasc Dis 2009; 19: 563-70; http://dx.doi.org/10.1016/j.numecd.2008.10.007

85. Salas-Salvadó J, Fernández-Ballart J, Ros E, et al. PREDIMED Study Investigators. Effect of a Mediterranean diet supplemented with nuts on metabolic syndrome status: one-year results of the PREDIMED randomized trial. Arch Intern Med 2008; 168: 2449-58; http://dx.doi.org/10.1001/ archinte.168.22.2449

86. Zulet MA, Bondia-Pons I, Abete I, et al. The reduction of the metabolic syndrome in NavarraSpain (RESMENA-S) study: a multidisciplinary strategy based on chrono-nutrition and nutritional education, together with dietetic and psychological control. Nutr Hosp 2011; 26: 16-26

87. Nomikos T, Detopoulou P, Fragopoulou E, et al. Boiled wild artichoke reduces postprandial glycemic and insulinemic responses in normal subjects but has no effect on metabolic syndrome patients. Nutr Res 2007; 27: 741-9; http://dx.doi.org/10.1016/j.nutres.2007.09.009

88. Lerman RH, Minich DM, Darland G, et al. Subjects with elevated LDL cholesterol and metabolic syndrome benefit from supplementation with soy protein, phytosterols, hops rho iso-alpha acids, 
and Acacia nilotica proanthocyanidins. J Clin Lipidol 2010; 4: 59-68; http://dx.doi.org/10.1016/j. jacl.2009.11.002

89. Wu H, Pan A, Yu Z, et al. Lifestyle counseling and supplementation with flaxseed or walnuts influence the management of metabolic syndrome. J Nutrition 2010; 140: 1937-42; http://dx.doi. org/10.3945/jn.110.126300

90. Muzio F, Mondazzi L, Harris WS, et al. Effects of moderate variations in the macronutrient content of the diet on cardiovascular disease risk factors in obese patients with the metabolic syndrome. Am J Clin Nutr 2007; 86: 946-51

91. Nakata Y, Okura T, Matsuo T, et al. Factors alleviating metabolic syndrome via diet-induced weight loss with or without exercise in overweight Japanese women. Prev Med 2009; 48: 351-6; http://dx.doi.org/10.1016/j.ypmed.2009.01.013

92. Paniagua JA, Pérez-Martinez P, Gjelstad I, et al. A low-fat high-carbohydrate diet supplemented with long-chain n-3 PUFA reduces the risk of the metabolic syndrome. Atherosclerosis 2011; 218: 443-50; http://dx.doi.org/10.1016/j.atherosclerosis.2011.07.003

93. König D, Deibert P, Frey I, et al. Effect of meal replacement on metabolic risk factors in overweight and obese subjects. Ann Nutr Metab 2008; 52: 74-8; http://dx.doi.org/10.1159/000119416

94. Camhi SM, Stefanick ML, Ridker PM, et al. Changes in C-reactive protein from low-fat diet and/ or physical activity in men and women with and without metabolic syndrome. Metabolism 2010; 59: 54-61; http://dx.doi.org/10.1016/j.metabol.2009.07.008

95. Trovato GM. Behavior, nutrition and lifestyle in a comprehensive health and disease paradigm: skills and knowledge for a predictive, preventive and personalized medicine. EPMA J 2012; 3: 8; http://dx.doi.org/10.1007/s13167-012-0141-2

96. Mecca MS, Moreto F, Burini FHP, et al. Ten-week lifestyle changing program reduces several indicators for metabolic syndrome in overweight adults. Diabetol Metab Syndr 2012; 4: 1-7; http:// dx.doi.org/10.1186/1758-5996-4-1

97. Groeneveld IF, Prope KI, Beek AJ, et al. Short and long term effects of a lifestyle intervention for construction workers at risk for cardiovascular disease: a randomized controlled trial. BMC Public Health 2011; 11: 836; http://dx.doi.org/10.1186/1471-2458-11-836

98. Bhat G, Baba CS, Pandey A, et al. Lifestyle modification improves insulin resistance and liver histology in patients with non-alcoholic fatty liver disease. World J Hepatol 2012; 4: 209-17; http:// dx.doi.org/10.4254/wjh.v4.i7.209

99. Dutheil F, Lesourd B, Courteix D, et al. Blood lipids and adipokines concentrations during a 6-month nutritional and physical activity intervention for metabolic syndrome treatment. Lipids Health Dis 2010; 9: 148; http://dx.doi.org/10.1186/1476-511X-9-148

100. Goodpaster BH, DeLany JP, Otto AD, et al. Effects of Diet and Physical Activity Interventions on Weight Loss and Cardiometabolic Risk Factors in Severely Obese Adults: A Randomized Trial. JAMA 2010; 304: 1795-802; http://dx.doi.org/10.1001/jama.2010.1505

101. Phelan S, Wadden TA, Berkowitz RI, et al. Impact of weight loss on the metabolic syndrome. Int J Obes 2007; 31: 1442-8; http://dx.doi.org/10.1038/sj.ijo.0803606

102. Villareal DT, Miller BV $3^{\text {rd }}$, Banks M, et al. Effect of lifestyle intervention on metabolic coronary heart disease risk factors in obese older adults. Am J Clin Nutr 2006; 84: 1317-23

103. Case CC, Jones $\mathrm{PH}$, Nelson K, et al. Impact of weight loss on the metabolic syndrome. Diabetes Obes Metab 2002; 4: 407-14; http://dx.doi.org/10.1046/j.1463-1326.2002.00236.x

104. Jen Jou H, Hsu IP, Huang HT, et al. A Hospital-Based Therapeutic Lifestyle Program for Women with Metabolic Syndrome. Taiwan J Obstet Gynecol 2010; 49: 432-7; http://dx.doi.org/10.1016/ S1028-4559(10)60094-0

105. Oh EG, Hyun SS, Kim SH, et al. A randomized controlled trial of therapeutic lifestyle modification in rural women with metabolic syndrome: a pilot study. Metabolism 2008; 57: 255-61; http:// dx.doi.org/10.1016/j.metabol.2007.09.009 
106. Seligman BG, Polanczyk CA, Santos AS, et al. Intensive practical lifestyle intervention improves endothelial function in metabolic syndrome independent of weight loss: a randomized controlled trial. Metabolism 2011; 60: 1736-40; http://dx.doi.org/10.1016/j.metabol.2011.05.006

107. Kim MH, Kim MK, Choi BY, et al. Prevalence of Metabolic Syndrome and its association with cardiovascular disease in Korea. J Korean Med Sci 2004; 19: 195-201; http://dx.doi.org/10.3346/ jkms.2004.19.2.195

108. Lusis AJ, Attie AD, Reue K. Metabolic syndrome: from epidemiology to systems biology. Nat Rev Genet 2008; 9: 819-30; http://dx.doi.org/10.1038/nrg2468

109. Manolio TA. Cohort studies and the genetics of complex disease. Nat Genet 2009; 41: 5-6; http:// dx.doi.org/10.1038/ng0109-5

110. Ikonomova K. Inflammation and Metabolic Syndrome. Turk J Endocrinol Metab 2004; 3: 85-9

111. Byrne CD, Wild SH. The Metabolic Syndrome, $2^{\text {nd }}$ Ed, John Wiley and Sons, 2011

112. Park TG, Hong HR, Lee J, et al. Lifestyle plus exercise intervention improves metabolic syndrome markers without change in adiponectin in obese girls. Ann Nutr Metab 2007; 51: 197-203; http:// dx.doi.org/10.1159/000104137

113. Bo S, Ciccone G, Guidi S, et al. Diet or exercise: what is more effective in preventing or reducing metabolic alterations? Eur J Endocrinol 2008; 159: 685-91; http://dx.doi.org/10.1530/EJE-08-0334

114. Trøseid M, Arnesen H, Seljeflot I. Nutritional and Therapeutic Interventions for Diabetes and Metabolic Syndrome. Chapter 20 Interleukin-18 in Metabolic Syndrome and Diabetes 2012: 253-64

115. Tahara A, Osaki Y, Kishimoto T. Influence of beta 3-adrenergic receptor Trp64Arg polymorphism on the improvement of metabolic syndrome by exercise-based intervention in Japanese middleaged males. Environ Health Prev Med 2010; 15: 392-7; http://dx.doi.org/10.1007/s12199-0100157-y

116. Vissers D, Vanroy C, De Meulenaere A, et al. Metabolic syndrome in youth: a cross-sectional schoolbased survey. Acta Paediatr 2007; 96: 1809-13; http://dx.doi.org/10.1111/j.1651-2227.2007.00528.x

117. Vissers D, Meulenaere AD, Vanroy C, et al. Effect of a multidisciplinary school-based lifestyle intervention on body weight and metabolic variables in overweight and obese youth. e-SPEN, the European e-Journal of Clinical Nutrition and Metabolism 2008; 3: e196-e202; http://dx.doi. org/10.1016/j.eclnm.2008.05.002

118. Magarey AM, Daniels LA, Boulton TJ, et al. Predicting obesity in early adulthood from childhood and parental obesity. Int J Obes Relat Metab Disord 2003; 27: 505-13; http://dx.doi.org/10.1038/ sj.ijo.0802251

119. Berenson GS, Srinivasan SR, Bao W, et al. Association between multiple cardiovascular risk factors and atherosclerosis in children and young adults. N Engl J Med 1998; 338: 1650-6; http://dx.doi. org/10.1056/NEJM199806043382302

120. Reinehr T, Kleber M, Toschke AM. Lifestyle intervention in obese children is associated with a decrease of the metabolic syndrome prevalence. Atherosclerosis 2009; 207: 174-80; http://dx.doi. org/10.1016/j.atherosclerosis.2009.03.041

121. Chen W, Srinivasan SR, Li S, et al. Clustering of Long-term Trends in Metabolic Syndrome Variables from Childhood to Adulthood in Blacks and Whites: The Bogalusa Heart Study. Am J Epidemiol 2007; 166: 527-33; http://dx.doi.org/10.1093/aje/kwm105

122. Kousar R, Burns C, Lewandowski P. A culturally appropriate diet and lifestyle intervention can successfully treat the components of metabolic syndrome in female Pakistani immigrants residing in Melbourne, Australia. Metabolism 2008; 57: 1502-8; http://dx.doi.org/10.1016/j.metabol.2008.06.003

123. Caranti DA, de Mello MT, Prado WL, et al. Short- and long-term beneficial effects of a multidisciplinary therapy for the control of metabolic syndrome in obese adolescents. Metabolism 2007; 56: 1293-300; http://dx.doi.org/10.1016/j.metabol.2007.05.004 
124. Brook RD, Bard RL, Glazewski L, et al. Effect of short term weight loss on the metabolic Syndrome and conduit vascular endothelial function in overweight adults. Am J Cardiol 2004; 93: 1012-6; http://dx.doi.org/10.1016/j.amjcard.2004.01.009

125. Watkins LL, Sherwood A, Feinglos M, et al. Effects of exercise and weight loss on cardiac risk factors associated with syndrome X. Arch Intern Med 2003; 163: 1889-95; http://dx.doi.org/10.1001/ archinte.163.16.1889

126. Yannakoulia M. Eating Behavior among Type 2 Diabetic Patients: A Poorly Recognized Aspect in a Poorly Controlled Disease. Rev Diabet Stud 2006; 3: 11-6; http://dx.doi.org/10.1900/RDS.2006.3.11

127. Pettman TL, Misan GMH, Owen K, et al. Self-management for obesity and cardio-metabolic fitness: description and evaluation of the lifestyle modification program of a randomised controlled trial. Int J Behavioral Nutr Phys Act 2008; 5: 53; http://dx.doi.org/10.1186/1479-5868-5-53

128. Straznicky NE, Grima MT, Eikelis N, et al. The effects of weight loss versus weight loss maintenance on sympathetic nervous system activity and metabolic syndrome components. J Clin Endocrinol Metab 2011; 96: E503-8; http://dx.doi.org/10.1210/jc.2010-2204

129. Fappa E, Yannakoulia M, Pitsavos C, et al. Lifestyle intervention in the management of metabolic syndrome: could we improve adherence issues? Nutrition 2008; 24: 286-91; http://dx.doi. org/10.1016/j.nut.2007.11.008

130. Bosak K. Managing Metabolic Syndrome: Focus on Physical Activity. The Journal for Nurse Practitioners 2012; 8: 206-11; http://dx.doi.org/10.1016/j.nurpra.2011.09.001

131. Lerman R. A Nutritional Approach to the Metabolic Syndrome. Functional Foods in Health and Disease 2011; 2: 38-49

132. Aounallah-Skhiri H, Traissac P, Ati JE, et al. Nutrition transition among adolescents of a southMediterranean country: dietary patterns, association with socio-economic factors, overweight and blood pressure. A cross-sectional study in Tunisia. Nutr J 2011; 10: 38; http://dx.doi. org/10.1186/1475-2891-10-38

133. Fappa E, Yannakoulia M, Pitsavos C, et al. Lifestyle intervention in the management of metabolic syndrome: could we improve adherence issues? Nutrition 2008; 24: 286-91; http://dx.doi. org/10.1016/j.nut.2007.11.008

134. Lin YC, Lyle RM, McCabe LD, et al. Dairy Calcium is related to Changes in Body Composition during a Two-Year Exercise Intervention in Young Women. J Am Coll Nutr 2000; 19: 754-60

135. Wijesuriya M, Gulliford M, Vasantharajah L, et al. DIABRISK-SL Prevention of cardio-metabolic disease with life style modification in young urban Sri Lankan's - study protocol for a randomized controlled trial. Trials 2011; 12: 209; http://dx.doi.org/10.1186/1745-6215-12-209

136. Lofrano-Prado MC, Antunes HKM, do Prado WL, et al. Quality of life in Brazilian obese adolescents: effects of a long-term multidisciplinary lifestyle therapy. Health Qual Life Outcomes 2009; 7: 61-8; http://dx.doi.org/10.1186/1477-7525-7-61

137. Lerman RH, Minich DM, Darland G, et al. Enhancement of a modified Mediterranean-style, low glycemic load diet with specific phytochemicals improves cardiometabolic risk factors in subjects with metabolic syndrome and hypercholesterolemia in a randomized trial. Nutrition \& Metabolism 2008; 5: 29-44; http://dx.doi.org/10.1186/1743-7075-5-29

138. Straznicky NE, Lambert EA, Nestel PJ, et al. Sympathetic Neural Adaptation to Hypocaloric Diet with or Without Exercise Training in Obese Metabolic Syndrome Subjects. Diabetes 2010; 59: 71 9; http://dx.doi.org/10.2337/db09-0934 